\title{
The di-tert-Butyl Oxymethylphosphonate Route to the Antiviral Drug Tenofovir
}

\author{
Jule-Philipp Dietz, ${ }^{[a]}$ Dorota Ferenc, ${ }^{[a]}$ Timothy F. Jamison, ${ }^{[b]}$ B. Frank Gupton, ${ }^{[c]}$ Till Opatz $*[a]$ \\ ${ }^{[a]}$ Department of Chemistry, Johannes Gutenberg-University, Duesbergweg 10-14, 55128 \\ Mainz, Germany \\ ${ }^{[b]}$ Department of Chemistry, Massachusetts Institute of Technology, 77 Massachusetts Avenue, \\ Cambridge, Massachusetts 02139, United States \\ ${ }^{[c]}$ Department of Chemical and Life Sciences Engineering, Virginia Commonwealth University, \\ Richmond, Virginia 23284, United States
}

Keywords: tenofovir, tert-butyl phosphite, tert-butyl oxymethyl phosphonates, adefovir

Di-tert-butyl oxymethyl phosphonates were investigated regarding their suitability of preparing the active pharmaceutical ingredient tenofovir (PMPA). First, an efficient and simple method for making the crystalline di-tert-butyl (hydroxymethyl)phosphonate was developed. Its $O$-mesylation gave high yields of the active phosphonomethylation reagent. For the synthesis of tenofovir, a twostep sequence was developed using $\mathrm{Mg}\left(\mathrm{O}^{t} \mathrm{Bu}\right)_{2}$ as the base for the alkylation of $(R)-9-(2-$ hydroxypropyl)adenine. Subsequent phosponate deprotection could be achieved with aqueous 
acids. (Di-tert-butoxyphosphoryl)methyl methanesulfonate showed to be most efficient electrophile, affording PMPA in $72 \%$ yield on a $5 \mathrm{~g}$ scale. The developed protocol could also be applied for the preparation of the hepatitis B drug adefovir (64\% yield in $1 \mathrm{~g}$ scale).

\section{Introduction}

The nucleotide reverse transcriptase inhibitor tenofovir (1, PMPA), which was discovered by A. Holy in $1993^{1}$, currently belongs to the most frequently applied HIV medications. To enable oral application and to increase bioavailability, a prodrug unit is required, which led to the development of tenofovir disoproxil fumarate (2, TDF, Viread $\left.{ }^{\circledR}\right)$ which was approved by the FDA for HIV treatment in 2001 and later in 2008 for hepatitis B virus therapy. ${ }^{2}$ In 2010, tenofovir alafenamide fumarate (3, TAF, Vemlidy ${ }^{\circledR}$ ) (Figure 1) was launched which showed fewer side effects and better tolerability than TDF. ${ }^{3}$

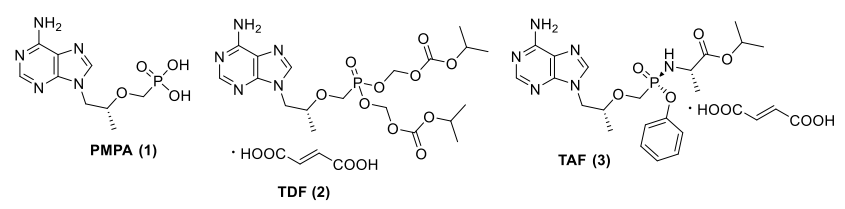

Figure 1: Structures of tenofovir (PMPA, 1), tenofovir disoproxil fumarate (TDF, 2) and tenofovir alafenamid fumarate (TAF, 3).

In the course of the 2020 COVID-19 pandemic, testing tenofovir as potential medication for SARS-CoV2 also moved in the focus of attention. It could be demonstrated that the triphosphate of tenofovir inhibits the RNA-dependent RNA polymerase of this virus in vitro. ${ }^{4}$ These results were supported by a study which investigated the incidence and severity of COVID-19 from 77590 HIV-positive persons receiving anti-retroviral therapy. There was a lower risk for COVID-19, less related hospitalization and even no mortality for people who were treated with Truvada ${ }^{\circledR}$ (TDF + 
FTC (emtricitabine)) than for people who had taken other antiviral drugs. ${ }^{5}$ There is also an ongoing clinical study in Spain with 4000 medical workers investigating Truvada ${ }^{\circledR}$ as potential prophylaxis for COVID-19. ${ }^{6}$ Thus, the demand of tenofovir could further rise in future. Due to a lack of a diverse set of industrial syntheses of tenofovir, raw material dependency can lead to unsteady prices and drug shortages. Therefore, diversification of the synthetic portfolio is an attractive goal.

The state-of-the-art synthesis of PMPA has been reported by the Clinton Health Access Initiative (CHAI) in 2010 (Scheme 1). (R)-9-(2-Hydroxypropyl)adenine (HPA, 4) undergoes a basemediated alkylation with diethyl ( $p$-toluenesulfonyloxymethane)phosphonate (DESMP, 5) followed by a one-pot deprotection of the phosphonic acid ester. CHAI reported that using $\mathrm{Mg}\left(\mathrm{O}^{t} \mathrm{Bu}\right)_{2}$ as a base showed the best conversion (>90\%) for the alkylation. Telescoping the two steps showed to be beneficial to circumvent the inconvenient work-up and the continuous extraction of the water-soluble phosphonate ester $\mathbf{6}$. Furthermore, the costs of the deprotection step could be reduced by replacing the hitherto used expensive $\mathrm{TMSBr}^{7}$ by $\mathrm{TMSCl} / \mathrm{NaBr}$. However, the work up was still elaborate as several filtration and extraction steps were required while simultaneously avoiding any moisture. Despite a reported significant loss of product in the magnesium salt cake (up to $15 \%$ ) PMPA $\cdot \mathrm{H}_{2} \mathrm{O}$ could be isolated in $59 \%$ yield. ${ }^{8}$ 


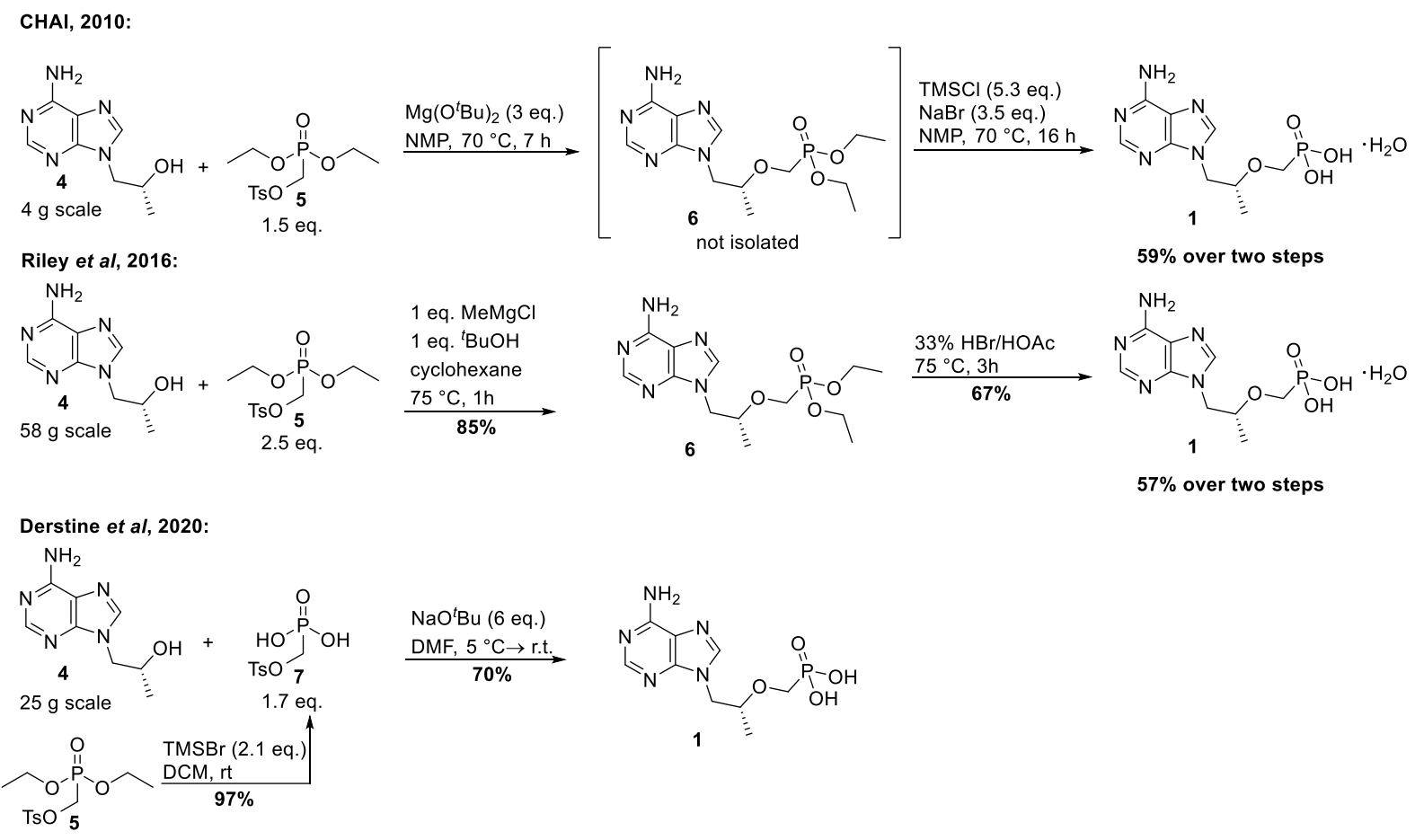

Scheme 1: Overview to hitherto scalable PMPA syntheses.

In 2016, Riley et al. reported that $\mathrm{Mg}\left(\mathrm{O}^{t} \mathrm{Bu}\right)_{2}$ could be substituted through its in situ generation by using $\mathrm{MeMgCl}$ and ${ }^{t} \mathrm{BuOH}$. The group developed an improved method to isolate the phosphonate diester 6 after continuous extraction in $85 \%$ yield. Subsequent deprotection with $\mathrm{HBr} /$ acetic acid afforded PMPA $\cdot \mathrm{H}_{2} \mathrm{O}$ in $67 \%$ yield (57\% over two steps) (Scheme 1$) .{ }^{9}$ Recently, Derstine et al. published a new approach for making PMPA on a multigram scale. They were able to find conditions to alkylate HPA with the free phosphonic acid of DESMP (7) by using $\mathrm{NaO} t \mathrm{Bu}$ as base in DMF. This very efficient process furnished PMPA in 70\% yield. ${ }^{10}$

It is conspicuous that all reports investigating the challenging synthesis of PMPA focused only DESMP (5) or the derived free acid 7 as alkylating agents with HPA. One big selling point is of course the fact that DESMP can be made from cheap commodity chemicals and has an industrial well-established process. Nevertheless, the overall yield starting from diethyl phosphite (8) has been reported to be only $60-70 \%$ with varying degrees of purity (Scheme 2). ${ }^{11}$ 


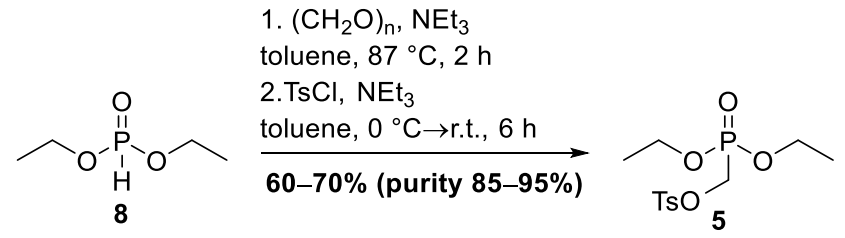

Scheme 2: Industrial synthesis of DESMP (5).

The biggest drawback of using DESMP in the synthesis of PMPA remains the deprotection of the diethyl ester. Beside expensive $\left(\mathrm{TMSBr}^{6}\right)$ or excessive amounts of reagents $\left(\mathrm{TMSCl} / \mathrm{NaBr}^{8}\right)$ an elaborate work-up including several filtrations and extractions is necessary. Silicon-containing byproducts have also been reported when using silyl agents. ${ }^{12}$ Other conditions (aq. $\mathrm{HBr}$, dry $\mathrm{HCl}$ gas, $\mathrm{AlCl}_{3}{ }^{13}$, or $\mathrm{HOAc} / \mathrm{HBr}^{9}$ ) led to lower yields. There is no variation of the alkyl group of oyxmethyl phosphonates reported in literature than the use of diisopropyl ester which requires similar conditions for the deprotection as the diethyl ester $\mathbf{6} .^{14,15}$

Tert-butyl phosphonates ${ }^{16,17}$ are also known for being deprotected under aqueous acidic conditions. In this report, the synthesis of di-tert-butyl oxymethyl phosphonates and their suitability for preparing PMPA (1) was investigated. An industrially feasible process was the aim of this work (Scheme 3).

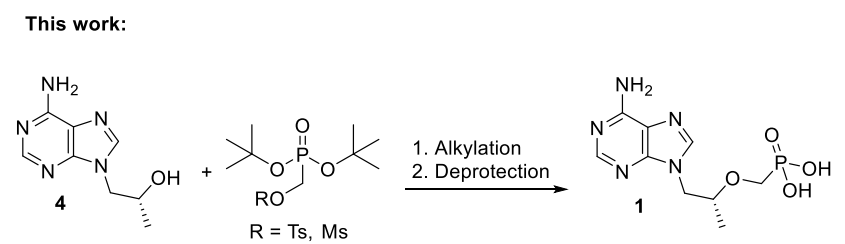

Scheme 3: Proposed synthesis for PMPA using tert-butyl oxymethyl phosphonates.

2. Discussion/results

2.1 Synthesis of di-tert-butyl phosphite 
Di-tert-butyl phosphite 9 is a commercially available but expensive compound. According to the literature, it can be synthesized by adding $\mathrm{PCl}_{3}$ to a cooled solution of tert-butanol in presence of a base (triethylamine, pyridine or dimethylaniline) in a nonpolar solvent (ligroin, petroleum ether, diethyl ether). The reported yields vary widely $(40-77 \%){ }^{18-23}$ Chemoselectivity (triester 10 vs diester 9) also proved to be an issue. ${ }^{24}$

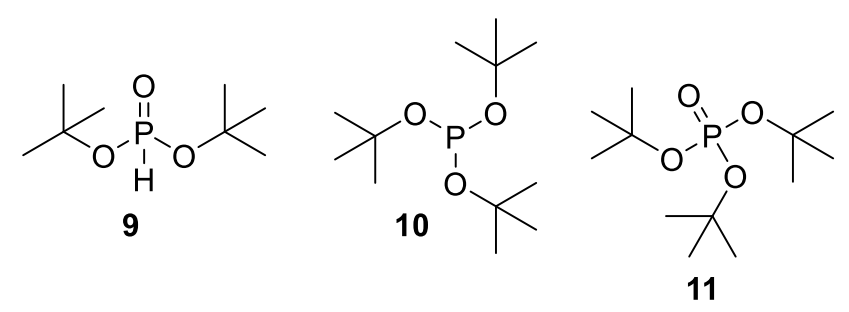

Figure 2: Structures of di-tert butyl phosphite (9), tri-tert butyl phosphite (10) and tri-tert butyl phosphate (11).

V. Mark and J. R. Van Wazer, who focused their investigations on the selective synthesis of tritert-butyl phosphite (10), enlightened more details about the reaction of $\mathrm{PCl}_{3}$ and tert-butanol. They proved that almost only triester $\mathbf{1 0}$ forms in the reaction Nevertheless, $\mathbf{1 0}$ decomposes quickly at $50^{\circ} \mathrm{C}$ under reduced pressure yielding the diester 9 . Furthermore, they reported that triester $\mathbf{1 0}$ was prone to rapid oxidation by air oxygen resulting in the formation of tri-tert-butyl phosphate (11). In terms of the selective synthesis of the diester, 11 represents an undesired byproduct which can only be circumvented by strict exclusion of oxygen during preparation and work-up. The reported varying yields could be explained by the fact that diester 9 has been reported to be very sensitive to incautious heating and some product is lost during distillation. ${ }^{19,20}$ In order to make tert-butyl phosphite interesting for an industrial application, the development of a more efficient synthesis was attempted. 
It appeared worth trying to use potassium tert-butoxide in the reaction with $\mathrm{PCl}_{3}$ instead of tertbutanol and an organic base. As a benefit, $\mathrm{KO}^{t} \mathrm{Bu}$ would combine both reagent and base while only potassium chloride would be accumulated as a co-product. In initial experiments, $\mathrm{PCl}_{3}$ was added to a $\mathrm{KO}^{t} \mathrm{Bu} / \mathrm{THF}$ solution while cooling. Following the reaction by ${ }^{1} \mathrm{H} /{ }^{31} \mathrm{P}-\mathrm{NMR}$ spectroscopy revealed also the formation of triester, diester and phosphate However, when the order of addition was reversed, predominant diester formation could be observed. Furthermore, adding solid $\mathrm{KO}^{t} \mathrm{Bu}$ instead of a THF-solution, which was slightly more convenient regarding handling, gave similar results. For the work-up, the reaction mixture was quenched with saturated $\mathrm{NaHCO}_{3}$-solution to maintain a basic $\mathrm{pH}$ in order to prevent acid-catalyzed cleavage of the tert-butyl groups. It is worth mentioning that despite a second aqueous washing step all the product remained in the organic phase and no further extraction was necessary. Using 3.0 eq. of $\mathrm{KO}{ }^{t} \mathrm{Bu}, 98 \%$ of crude $9\left({ }^{31} \mathrm{P}-\mathrm{NMR}\right.$ purity: 75\%) was obtained after work-up (Table 1, entry 1). During further investigations it turned out that subsequent reduction of the equivalents of $\mathrm{KO}^{t} \mathrm{Bu}$ improved the purity of the crude product (Table 1, entry 2-5). When the reaction was performed with 2.5 eq. of $\mathrm{KO}^{t} \mathrm{Bu}, 76 \%$ of crude 9 could be obtained showing a high purity in the ${ }^{1} \mathrm{H} \&{ }^{31} \mathrm{P}$-NMR spectrum (see the supporting information for more details).

Table 1: Screening equivalents of KOtBu for the synthesis of di-tert-butyl phosphite.

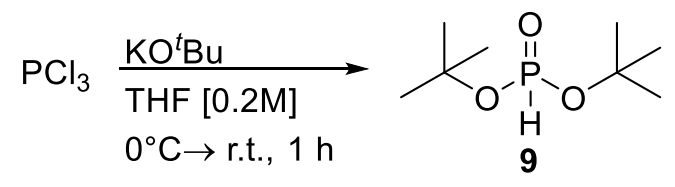

\begin{tabular}{cccc}
\hline & KOtBu & yield & purity \\
$\#$ & (eq.) & {$[\%] a$} & {$[\%] b$}
\end{tabular}




\begin{tabular}{cccc}
\hline $\mathbf{1}$ & 3.0 & 98 & 75 \\
\hline $\mathbf{2}$ & 2.9 & 85 & 91 \\
\hline $\mathbf{3}$ & 2.7 & 84 & 95 \\
\hline $\mathbf{4}$ & 2.5 & 76 & 97 \\
\hline $\mathbf{5}$ & 2.3 & 69 & 99
\end{tabular}

All reactions were performed on a $3 \mathrm{~g}$ scale; a crude isolated yield; b determined by $31 \mathrm{P}-\mathrm{NMR}$ spectroscopy.

Using the water-soluble THF as solvent had the drawback that large amounts of sodium sulfate had to be used for drying the organic phase. Therefore, less water-soluble alternative solvents were investigated for the reaction. CPME (cyclopentyl methyl ether), Me-THF and even MTBE showed similar results regarding yield and purity (Table 2).

Table 2: Solvent screening for the synthesis of tert-butyl phosphite.

\begin{tabular}{ccccc}
\hline$\#$ & solvent & $\begin{array}{c}\mathbf{K O}^{\boldsymbol{t}} \mathbf{B u} \\
\text { (eq.) }\end{array}$ & $\begin{array}{c}\text { Yield } \\
{[\mathbf{\%}]^{\mathbf{a}}}\end{array}$ & $\begin{array}{c}\text { Purity } \\
{[\mathbf{\%}]^{\mathbf{b}}}\end{array}$ \\
\hline $\mathbf{1}$ & THF & 2.5 & 76 & 97 \\
\hline $\mathbf{2}$ & Me-THF & 2.5 & 75 & 99 \\
\hline $\mathbf{3}$ & CPME & 2.5 & 77 & 99 \\
\hline $\mathbf{4}$ & MTBE & 2.5 & 78 & 99
\end{tabular}

All reactions were performed on $3 \mathrm{~g}$ scale; ${ }^{\mathrm{a}}$ crude isolated yield; ${ }^{\mathrm{b}}$ determined by ${ }^{31} \mathrm{P}-\mathrm{NMR}-$ spectroscopy.

By focusing on MTBE and Me-THF as solvents, substitution of $\mathrm{KO}^{t} \mathrm{Bu}$ by the cheaper sodium salt further increased the yield of 9 (Table 3). When the reaction in MTBE was scaled-up, an increasing byproduct formation was observed whereas in Me-THF, the purity remained constant.

Table 3: Scale-up of the tert-butyl phosphite synthesis using NaOtBu. 


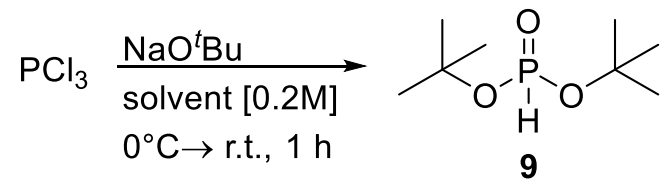

\begin{tabular}{cccccc}
\hline$\#$ & $\begin{array}{c}\text { scale } \\
{\left[\mathbf{g ~ P C l}_{3}\right]}\end{array}$ & solvent & $\begin{array}{c}\mathbf{N a O}^{\boldsymbol{t}} \mathbf{B u} \\
\mathbf{( e q . )}\end{array}$ & $\begin{array}{c}\text { IY } \\
{[\mathbf{\%}]^{\mathbf{a}}}\end{array}$ & $\begin{array}{c}\text { Purity } \\
{[\mathbf{\%}]^{\mathbf{b}}}\end{array}$ \\
\hline $\mathbf{1}$ & 3 & MTBE & 2.5 & 80 & 97 \\
\hline $\mathbf{2}$ & 6 & MTBE & 2.5 & 82 & 90 \\
\hline $\mathbf{3}$ & 3 & Me-THF & 2.5 & 86 & 95 \\
\hline $\mathbf{4}$ & 9 & Me-THF & 2.5 & 85 & 95
\end{tabular}

${ }^{\mathrm{a}}$ crude isolated yield; ${ }^{\mathrm{b}}$ determined by ${ }^{31} \mathrm{P}-\mathrm{NMR}$-spectroscopy.

The obtained crude di-tert-butyl phosphite was used for the hydroxymethylation without prior distillation to avoid an additional loss of product.

2.2 Hydroxymethylation of tert-butyl phosphite

A procedure for the hydroxymethylation of tert-butyl phosphite has already been reported in patent literature. ${ }^{25,26,26}$ According to this procedure, $9^{1}$ was stirred in the presence of aq. formaldehyde-solution, triethylamine and water at r.t. to furnish crude 12 in $99 \%$ yield. A ${ }^{31} \mathrm{P}$ NMR-spectrum showed about 10\% of impurities (Scheme 4).

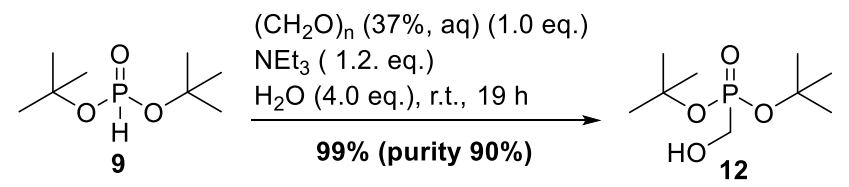

Scheme 4: Hydroxymethylation of tert-butyl phosphite using aq. formaldehyde solution.

${ }^{1}$ For this reaction commercial available tert-butyl phosphite $(96 \%)$ was used. 
For the work-up it was necessary to co-evaporate the reaction mixture several times with $\mathrm{MeOH}$ and DCM in order to remove water and triethylamine. Optimization attempts by replacing triethylamine by $\mathrm{K}_{2} \mathrm{CO}_{3}$ or omitting the additional water led to increased byproduct formation. In search for a simpler method, it turned out that using solid paraformaldehyde along with $\mathrm{K}_{2} \mathrm{CO}_{3}$ as base and acetonitrile as solvent showed promising results (Table 4). The reaction was followed by ${ }^{1} \mathrm{H}$ - and ${ }^{31} \mathrm{P}-\mathrm{NMR}$ spectroscopy, which revealed incomplete conversion after $19 \mathrm{~h}$ at $50{ }^{\circ} \mathrm{C}$ using $10 \mathrm{~mol} \% \mathrm{~K}_{2} \mathrm{CO}_{3}$ (Table 4, entry 1). Doubling the amount of base furnished complete conversion in the same time along with only small amounts of byproducts (Table 4, entry 2). Performing the reaction on a larger scale required higher temperature $\left(60^{\circ} \mathrm{C}\right)$ for completion in the same time (Table 4, entry 3). Further increasing of the temperature shortened reaction time significantly without increasing byproduct formation (Table 4, entry 4). When the reaction was performed on an $8 \mathrm{~g}$ scale, nearly pure 9 could be isolated in 99\% yield after work-up which only consisted of a single filtration and subsequent solvent removal in vacuo (Table 4, entry 5).

Table 4: Hydroxymethylation of tert-butyl phosphite using solid paraformaldehyde and $\mathrm{K}_{2} \mathrm{CO}_{3}$ in $\mathrm{MeCN}$.

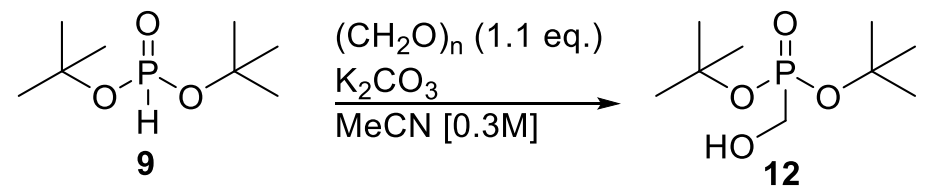

\begin{tabular}{ccccccc}
\hline$\#$ & $\begin{array}{c}\text { Scale } \\
\text { [g 9] }\end{array}$ & $\begin{array}{c}\mathrm{K}_{2} \mathbf{C O}_{3} \\
\text { (eq.) }\end{array}$ & $\begin{array}{c}\boldsymbol{T} \\
{\left[{ }^{\circ} \mathbf{C}\right]}\end{array}$ & $\begin{array}{c}\text { BP }] \\
{[\mathbf{\%}]^{\mathbf{a}}}\end{array}$ & $\begin{array}{c}\text { conversion } \\
{[\%]^{\mathbf{b}}}\end{array}$ \\
\hline $\mathbf{1}$ & 0.2 & 0.1 & 50 & 19 & 4 & 89 \\
\hline $\mathbf{2}$ & 0.2 & 0.2 & 50 & 19 & 2 & 98 \\
\hline $\mathbf{3}$ & 1.0 & 0.2 & 60 & 23 & 2 & 98 \\
\hline
\end{tabular}




\begin{tabular}{lllllll}
\hline $\mathbf{4}$ & 1.0 & 0.2 & 80 & 3 & 2 & 98 \\
\hline $\mathbf{5}$ & 8.0 & 0.2 & 80 & 4 & 1 & $99^{\mathrm{c}}$
\end{tabular}
${ }^{a}$ phosphorus-containing byproducts ${ }^{\mathrm{b}}$ determined by ${ }^{31} \mathrm{P}-\mathrm{NMR}$ spectroscopy; ${ }^{\mathrm{c}} 99 \%$ isolated yield
after work-up

It should be mentioned that only commercially or freshly distilled di-tert-butyl phosphite was used up to this point. When using crude di-tert-butyl phosphite, obtained from the newly developed protocol mentioned above, the purity was determined first by ${ }^{31} \mathrm{P}-\mathrm{NMR}$ spectroscopy in order to adjust the amount of paraformaldehyde. This was crucial as excess paraformaldehyde caused additional byproduct formation. During further investigations, it turned out that $\mathbf{1 2}$ could be recrystallized from $\mathrm{MeCN}$. When the filtered and concentrated reaction mixture was stored in a freezer, crystalline 12 could be isolated in $71 \%$ (based on $\mathrm{PCl}_{3}$ ) (Table 5, entry 1).

Table 5: Telescoped synthesis of di-tert-butyl (hydroxymethyl)phosphonate from $\mathrm{PCl}_{3}$.

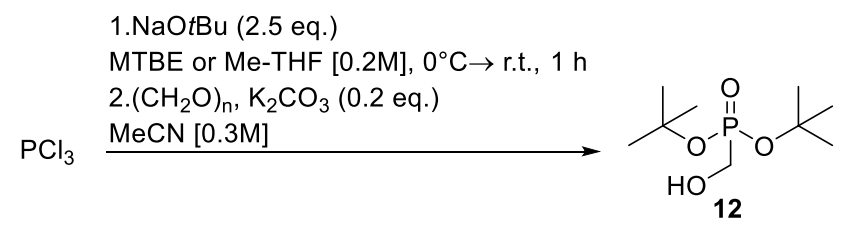

\begin{tabular}{cccccc}
\hline$\#$ & scale & $\left(\mathbf{C H}_{2} \mathbf{O}\right) \mathbf{n}$ & $\boldsymbol{T}$ & $\boldsymbol{t}$ & IY \\
& {$\left[\mathbf{g} \mathbf{9}^{\mathbf{a}}\right.$} & $(\mathbf{e q .})$ & {$\left[{ }^{\circ} \mathbf{C}\right]$} & {$[\mathbf{h}]$} & {$[\%]^{\mathbf{b}}$} \\
\hline $\mathbf{1}$ & $6.6(95)$ & 1.1 & 80 & 5 & 71 \\
\hline $\mathbf{2}^{\mathbf{d}}$ & $7.2(90)$ & 1.0 & 70 & 20 & 66 \\
\hline $\mathbf{3}^{\mathbf{d}}$ & $3.8(95)$ & 1.0 & 70 & 20 & 72 \\
\hline $\mathbf{4}^{\mathbf{d}}$ & $11.3(95)$ & 1.0 & 70 & 20 & 71 \\
\hline
\end{tabular}

\footnotetext{
${ }^{a}$ purity [\%] determined by ${ }^{31} \mathrm{P}-\mathrm{NMR}$-spectroscopy; ${ }^{\mathrm{b}}$ after recrystallization and based on $\mathrm{PCl}_{3}$; d flask gas room filled with argon
} 
Due to the volatility of the releasing formaldehyde the reactions were usually performed in a closed flask equipped with a septum and a nitrogen-filled balloon for pressure compensation. However, there were always small amounts of paraformaldehyde precipitating on the bottom of the septum. Therefore, a slight excess of paraformaldehyde ( 0.1 eq. $)$ had to be used. Depending on scale and reactor size the precipitating paraformaldehyde could lead to variable conversion and made unwelcome additional purification necessary. To circumvent this issue at least under laboratory conditions, it was efficient to fill the gas room of the flask and the balloon with argon. Paraformaldehyde precipitation could not be observed anymore and consequently the equivalents of paraformaldehyde could be further decreased to 1.0 eq. while temperature and time were also adjusted. Crude 9 derived from the esterification in MTBE could be hydroxymethylated in $66 \%$ yield (Table 5, entry 2) while crude $\mathbf{9}$ derived from the esterification in Me-THF furnished $\mathbf{1 2}$ in $72 \%$ (Table 5, entry 3). Up-scaling to a $11 \mathrm{~g}$ reaction afforded $\mathbf{1 2}$ in $71 \%$ yield. There is still space for optimization of this two-step sequence. With a more accurate method for determining the purity of crude tert-butyl phosphite (e.g. gas chromatography), the equivalents of paraformaldehyde could be adjusted more precisely giving less byproducts.

\subsection{Tosylation and mesylation of $\mathbf{1 2}$}

Sulfonation of the hydroxyl group of $\mathbf{1 2}$ has only been described for the expensive triflate. ${ }^{25}$ Tosylation and mesylation of $\mathbf{1 2}$ should be investigated as more economic alternatives. Under optimized conditions, (di-tert-butoxyphosphoryl)methyl 4-methylbenzenesulfonate (13) could be obtained in $87 \%$ yield after recrystallization from EtOH (Scheme 5). It should be noted that $\mathbf{1 3}$ is prone to rapid dealkylation in the presence of acids. When the reaction was performed without 
DMAP, traces of tosyl chloride present in the crude product were sufficient to slowly release $\mathrm{HCl}$ during recrystallization in EtOH which led to dealkylation.

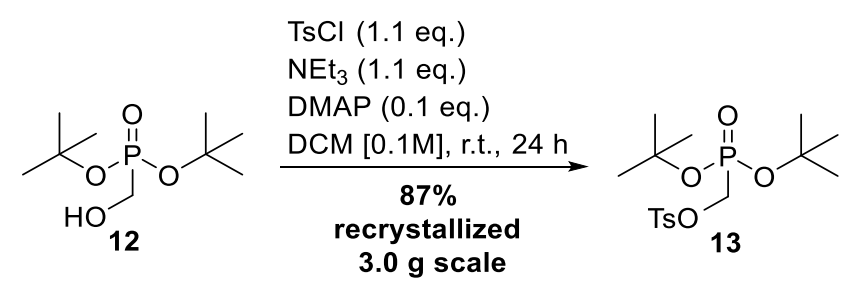

Scheme 5: Tosylation of di-tert-butyl (hydroxymethyl)phosphonate.

The mesylation of $\mathbf{1 2}$ proceeded more efficiently than the tosylation under similar conditions. Furthermore, no recrystallization was necessary as excessive mesyl chloride completely hydrolyzed during the aqueous work-up and no byproducts formed. Crystalline (di-tertbutoxyphosphoryl)methyl methanesulfonate (14) could be obtained in $97 \%$ yield even on multigram scale (Scheme 6).

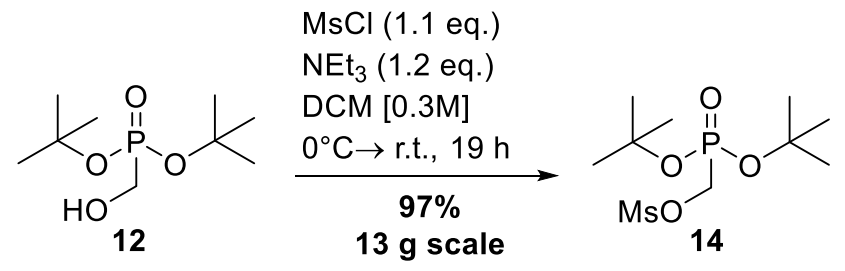

Scheme 6: Mesylation of di-tert-butyl (hydroxymethyl)phosphonate.

2.4 Synthesis of PMPA using tert-butyl oxymethyl phosphonates 13 and 14.

For screening the alkylation of HPA, the focus was laid on using mesylate $\mathbf{1 4}$ due to its more efficient preparation. Performing the reaction in DMF and using other bases than $\operatorname{Mg}\left(\mathrm{O}^{t} \mathrm{Bu}\right)_{2}$ such as $\mathrm{KOtBu}, \mathrm{NaOtBu}$ or $\mathrm{NaH}$ led to product mixtures containing both $N$-and $O$-alkylated HPA, bis- 
alkylated HPA and both isomers of 9-propenyladenine which probably had formed due to transesterification and subsequent elimination. The best results were achieved with $\operatorname{Mg}\left(\mathrm{O}^{t} \mathrm{Bu}\right)_{2}$ as the base. In a first screening, different aprotic polar solvents were investigated while an excess of mesylate 14 (2.5 eq.) was used to accomplish complete conversion of HPA. After stirring for $20 \mathrm{~h}$ at $80{ }^{\circ} \mathrm{C}$ in DMF, $96 \%$ conversion of HPA could be detected by HPLC. At lower temperatures the reaction proceeded much slower $\left(63 \%\right.$ conversion after $21 \mathrm{~h}$ at $\left.70{ }^{\circ} \mathrm{C}\right)$. Besides the desired diester 15, formation of the monoester $\mathbf{1 6}$ could be detected which had probably formed by thermal decomposition. Furthermore, the respective amidine of both esters (Figure 4, $\mathbf{1 7}$ and $\mathbf{1 8}$ ) as well as the formylated diester (Figure 4, 19) could be detected. Summing up the mono-and diester and supposing that the amidines also hydrolyze under aqueous acidic conditions $92 \%$ of potential PMPA had formed (Table 6, entry 2).

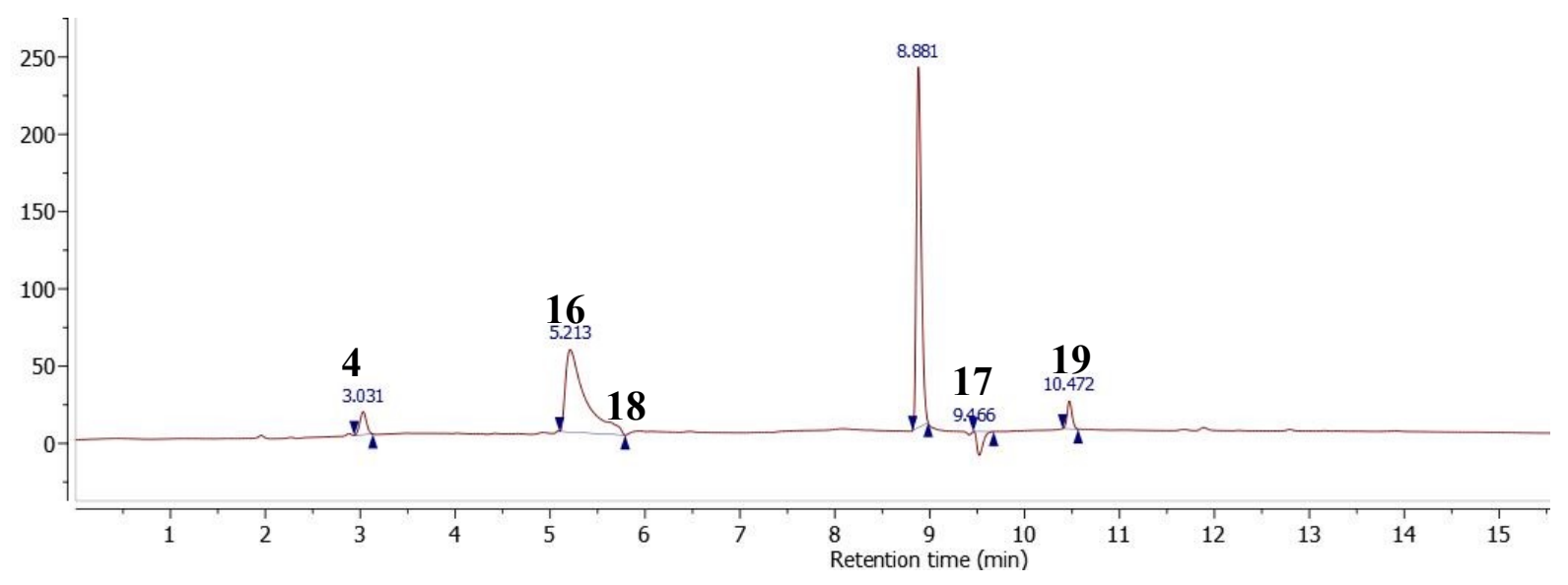

Figure 3: HPLC-Chromatogram of the alkylation of HPA with mesylate XX after $21 \mathrm{~h}$ in DMF at $80^{\circ} \mathrm{C}(\lambda=254 \mathrm{~nm})$. 

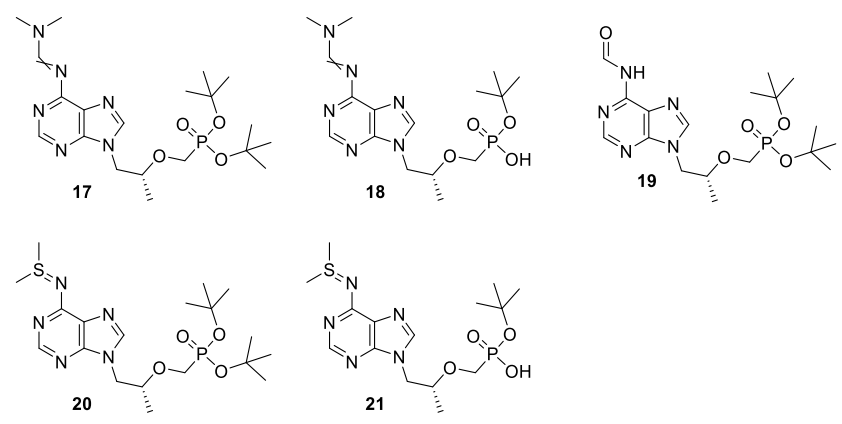

Figure 4: Occuring Impurities during alkylation of HPA with mesylate 14 in DMF and DMSO.

In DMSO, a slightly lower conversion of HPA (93\%) could be achieved at $70{ }^{\circ} \mathrm{C}$ after $21 \mathrm{~h}$. A larger percentage of diester 15 could be detected which was attributed to the lower temperature. The observed sulfinimides $\mathbf{2 0}$ and 21 (Figure 4) had formed in a reaction with DMSO. These compounds should also get hydrolyzed under acidic conditions, so that overall $87 \%$ of PMPA had formed in this reaction.

Table 6: Solvent screening of the alkylation of HPA with mesylate $\mathrm{XX}$ in presence of $\mathrm{Mg}(\mathrm{OtBu})_{2}$.

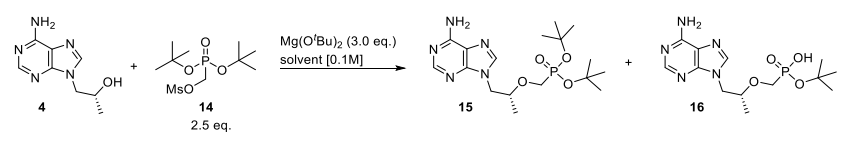

\begin{tabular}{ccccccccc}
\hline$\#$ & solvent & $\boldsymbol{T}\left[{ }^{\circ} \mathbf{C}\right]$ & $\boldsymbol{t}[\mathbf{h}]$ & $\mathbf{4}^{\mathbf{a}}$ & $\mathbf{1 6}^{\mathbf{a}}$ & $\mathbf{1 5}^{\mathbf{a}}$ & $\mathbf{B P}^{\mathbf{a}}$ & "PMPA" \\
\hline $\mathbf{1}$ & DMF & 80 & 21 & 4 & 43 & 49 & 4 & 92 \\
\hline $\mathbf{2}$ & DMSO & 70 & 21 & 7 & 5 & 76 & $12^{\mathrm{b}}$ & 87 \\
\hline $\mathbf{3}$ & NMP & 90 & 21 & 4 & 81 & 14 & 1 & 95 \\
\hline $\mathbf{4}$ & DMA & 90 & 21 & 2 & 88 & 8 & 2 & 96
\end{tabular}

All reactions were performed in a $0.02 \mathrm{~g}$ scale; ${ }^{\mathrm{a}}$ peak area $[\%](\lambda=254 \mathrm{~nm}) ;{ }^{\mathrm{b}}$ include $6 \%$ of sulfinimids; $\mathrm{BP}=$ byproducts 
The best results were observed when the $O$-alkylation was performed in $N$-methylpyrrolidone (NMP) or dimethyl acetamide (DMA) at $90^{\circ} \mathrm{C}$. Mainly monoester formation occurred along with only small amounts of byproducts. 95\% and 96\% (Figure 5) PMPA-formation could be detected, respectively (Table 6 , entry $3 \& 4$ ).

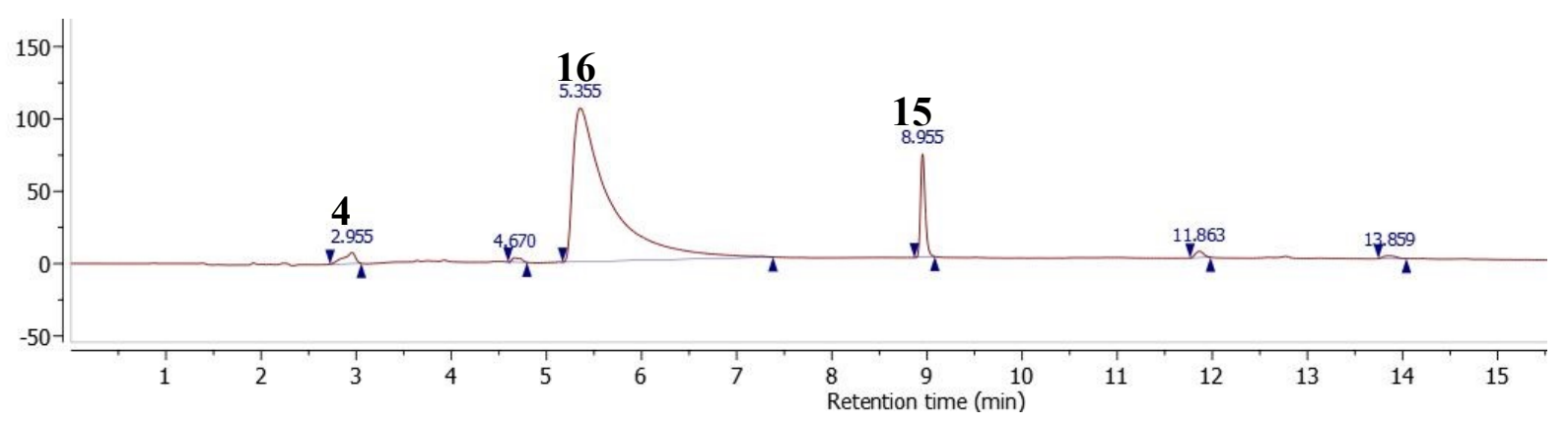

Figure 5: HPLC-Chromatogram of the alkylation of HPA with mesylate XX after $21 \mathrm{~h}$ in DMA at $90{ }^{\circ} \mathrm{C}(\lambda=254 \mathrm{~nm})$.

For further optimizations DMA was chosen as solvent. Regarding the amount of $\operatorname{Mg}\left(\mathrm{O}^{t} \mathrm{Bu}\right)_{2}$, it turned out that 3.0 equivalents were crucial to achieve high conversions (Table 7).

Table 7: Screening of $\mathrm{Mg}\left(\mathrm{O}^{t} \mathrm{Bu}\right)_{2}$ equivalents for the alkylation of HPA with mesylate 14 in DMA.

\begin{tabular}{ccc}
\hline$\#$ & $\begin{array}{c}\mathbf{M g}\left(\mathbf{O}^{t} \mathbf{B u}\right)_{2} \\
(\mathbf{e q .})\end{array}$ & $\begin{array}{c}\text { conversion } \\
{[\%]^{\mathbf{a}}}\end{array}$ \\
\hline $\mathbf{1}$ & 4.0 & 95 \\
\hline $\mathbf{2}$ & 3.5 & 94 \\
\hline $\mathbf{3}$ & 3.0 & 97 \\
\hline $\mathbf{4}$ & 2.5 & 65 \\
\hline $\mathbf{5}$ & 2.0 & 32 \\
\hline
\end{tabular}

All reactions were performed in a $0.02 \mathrm{~g}$ scale with $2.5 \mathrm{eq}$. mesylate and stirred for $21 \mathrm{~h}$ in DMA

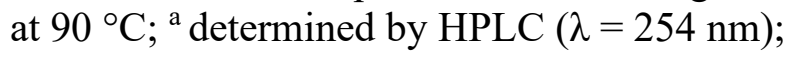


No significant difference in terms of conversion could be observed when the equivalents of mesylate were reduced from 2.5 to 2.0 (Table 8). Between 2.0 and 1.5 eq. the conversion varied between $90 \%$ and $98 \%$. Below 1.5 equivalents the conversion decreased noticeably. The varying conversion could arise from the low purity of $\operatorname{Mg}\left(\mathrm{O}^{t} \mathrm{Bu}\right)_{2}(93 \%)$ which can have a big effect in such small scale reactions.

Table 8: Screening equivalents of mesylate 14 for the alkylation of HPA.

\begin{tabular}{ccc}
\hline$\#$ & $\begin{array}{c}\text { XX } \\
\text { (eq.) }\end{array}$ & $\begin{array}{c}\text { conversion } \\
\text { [\% }^{\mathbf{a}}\end{array}$ \\
\hline $\mathbf{1}$ & 2.5 & $94-98$ \\
\hline $\mathbf{2}$ & 2.0 & $96-98$ \\
\hline $\mathbf{3}$ & 1.7 & $91-96$ \\
\hline $\mathbf{4}$ & 1.5 & $90-94$ \\
\hline $\mathbf{5}$ & 1.3 & $79-83$ \\
\hline
\end{tabular}

All reactions were performed twice in a $0.02 \mathrm{~g}$ scale with 3.0 eq. of $\mathrm{Mg}\left(\mathrm{O}^{t} \mathrm{Bu}\right)_{2}$ and stirred for $21 \mathrm{~h}$ in DMA at $90^{\circ} \mathrm{C} ;{ }^{\text {a }}$ determined by $\operatorname{HPLC}(\lambda=254 \mathrm{~nm})$

To cleave off the tert-butyl groups in order to generate PMPA, aqueous hydrochloric acid was added to the crude reaction mixture. Dealkylation was complete after stirring for $24 \mathrm{~h}$ at r.t.. When the reaction was performed on a larger scale (1 g), DMA was first removed in vacuo and aqueous acid $(3 \mathrm{~N} \mathrm{HCl})$ was added to the residue. At $60^{\circ} \mathrm{C}$, the dealkylation was already complete after $2 \mathrm{~h}$. The $\mathrm{pH}$ was adjusted to 2.8-3.0 with $\mathrm{NaOH}$-solution to precipitate $\mathrm{PMPA} \cdot \mathrm{H}_{2} \mathrm{O}$ which was dried afterwards as described in literature. ${ }^{10}$ On a $1 \mathrm{~g}$ scale, the conversion of HPA was slightly higher when using 1.7 eq. of $\mathbf{1 4}$ instead 1.5 eq. while the isolated yields were similar, $64 \%$ and $65 \%$, 
respectively (Table 9, entry $1 \& 2$ ). Despite the high conversions of HPA, large amounts of PMPA $\cdot \mathrm{H}_{2} \mathrm{O}$ did not precipitate and remained in the mother liquor.

Table 9: Two-step-sequence for making PMPA from HPA and mesylate 14.

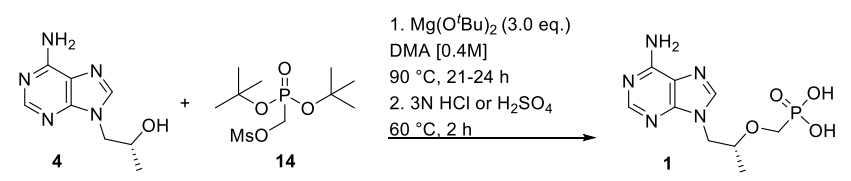

\begin{tabular}{cccccc}
\hline$\#$ & scale & XX & $\boldsymbol{t}$ & Conversion & IY \\
& {$[\mathbf{g ~ 4}]$} & (eq.) & {$[\mathbf{h}]$} & {$[\%]^{\mathbf{a}}$} & {$[\%]$} \\
\hline $\mathbf{1}^{\mathbf{b}}$ & 1.0 & 1.7 & 23 & 96 & 64 \\
\hline $\mathbf{2}^{\mathbf{b}}$ & 1.0 & 1.5 & 21 & 92 & 65 \\
\hline $\mathbf{3}^{\mathbf{c}}$ & 1.0 & 1.5 & 24 & 91 & 69 \\
\hline $\mathbf{4}^{\mathbf{c}}$ & 5.0 & 1.5 & 22 & 91 & 72 \\
\hline
\end{tabular}

${ }^{\mathrm{a}}$ determined by HPLC $(\lambda=254 \mathrm{~nm}),{ }^{\mathrm{b}}$ dealkylation/pH-adjustment performed with $3 \mathrm{~N}$ $\mathrm{HCl} / \mathrm{NaOH}(40 \mathrm{wt} \%) ;{ }^{\mathrm{c}}$ dealkylation/pH-adjustment performed with $3 \mathrm{~N} \mathrm{H}_{2} \mathrm{SO}_{4} / \mathrm{NH}_{3}(25 \mathrm{wt} \%)$

Several attempts were undertaken to isolate more PMPA from the mother liquor. When the mother liquor was concentrated and cooled again, mostly inorganic salts precipitated along with traces of PMPA. The same was observed when small amounts of water were added to the residue of the lyophilized mother liquor. The addition of co-solvents to the mother liquor like $\mathrm{MeOH}$, $\mathrm{EtOH},{ }^{i} \mathrm{PrOH}$ or $\mathrm{MeCN}$ also led only to the precipitation of a PMPA/salt mixtures from which PMPA could not be easily separated. As Derstine et al. have carefully analyzed, $\mathrm{NaCl}$, which forms during $\mathrm{pH}$-adjustment, has a large effect on keeping PMPA in solution. ${ }^{10}$ Therefore, in a further experiment aqueous $\mathrm{H}_{2} \mathrm{SO}_{4}$ was used for the dealkylation and the $\mathrm{pH}$ was adjusted with conc. aqueous $\mathrm{NH}_{3}(25 \mathrm{wt}-\%)$ in order to see how the forming $\left(\mathrm{NH}_{4}\right)_{2} \mathrm{SO}_{4}$ effects the PMPA- 
solubility. Only slightly more PMPA (69\%) could be isolated in this way (Table 9, entry 3). Nevertheless, performing the reaction on a $5 \mathrm{~g}$ scale, $72 \%$ of PMPA could be obtained (Table 9, entry 4).

Using the tosylate $\mathbf{1 3}$ for the alkylation of HPA similar conversions could be observed in DMA, DMSO and DMF (Table 10).

Table 10: Solvent screening of coupling HPA with tosylate 13 in presence of $\mathrm{Mg}(\mathrm{OtBu})_{2}$.

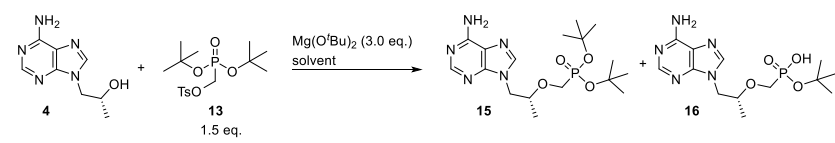

\begin{tabular}{ccccccccc}
\hline \# & solvent & $\boldsymbol{T}$ & $\boldsymbol{t}$ & & & & & \\
& & {$\left[{ }^{\circ} \mathbf{C}\right]$} & {$[\mathbf{h}]$} & & & & & \\
\hline $\mathbf{1}$ & DMA & 80 & 21 & 6 & 80 & 12 & 2 & 92 \\
\hline $\mathbf{2}$ & DMSO & 70 & 21 & 3 & 39 & 50 & 8 & 90 \\
\hline $\mathbf{3}$ & DMF & 80 & 21 & 4 & 82 & 12 & 2 & 94
\end{tabular}

All reactions were performed in a $0.02 \mathrm{~g}$ scale; ${ }^{\mathrm{a}}$ peak area $[\%](\lambda=254 \mathrm{~nm}) ; \mathrm{BP}=$ byproducts

When the reaction was performed in DMF on a $1 \mathrm{~g}$ scale $96 \%$ conversion of HPA was detected after $23 \mathrm{~h}$. After conducting the dealkylation and work-up in the same way as described for the mesylate, PMPA could be isolated in $68 \%$ yield (Scheme 7).

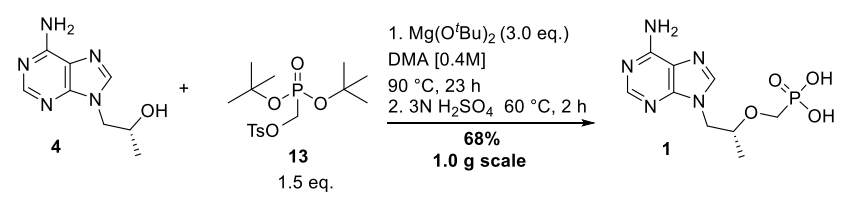

Scheme 7: Two-step-sequence for making PMPA from HPA and tosylate 13. 
All in all, there was no significant difference regarding isolated yield between the usage of mesylate $\mathbf{1 4}$ and tosylate $\mathbf{1 3}$ for preparing PMPA.

\subsection{Further application}

Both newly reported di-tert-butyl oxymethylphosphonates $\mathbf{1 3}$ and $\mathbf{1 4}$ could be also easily converted quantitatively to their free phosphonic acid by just heating them for a few minutes even under solvent free conditions (Scheme 8). In the case of tosylate 13, the method affords an alternative to the recently reported synthesis by Derstine et al. where the diethyl ester $\mathbf{5}$ was dealkylated with TMSBr. ${ }^{10}$

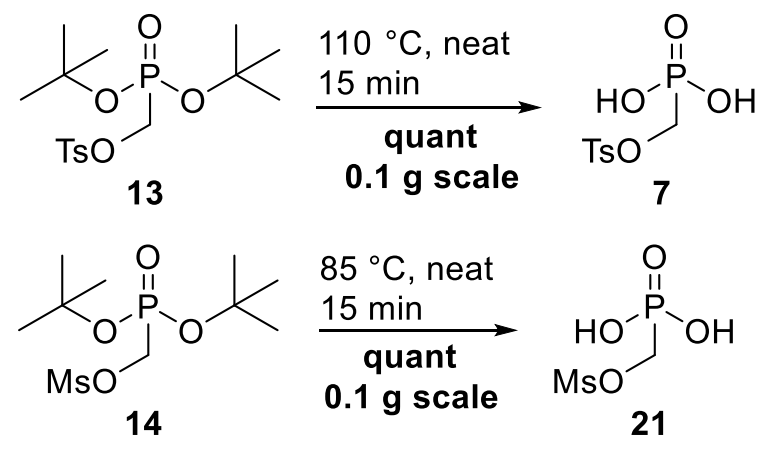

Scheme 8: Dealkylation of $\mathbf{1 3}$ and $\mathbf{1 4}$ to the free phosphonic acid by heating neat.

In general, other nucleotide-like APIs having an oxy-methyl phosphonate moiety are industrially prepared similar to PMPA. ${ }^{27,28}$ The hepatitis B inhibitor adefovir $\left(\right.$ Hepsera $\left.{ }^{\circledR}, 22\right)$ differs only in one methyl group from tenofovir. Applying the newly developed protocol on 9-(2hydroxyethyl)adenine (23) $87 \%$ conversion could be detected after $22 \mathrm{~h}$ at $90{ }^{\circ} \mathrm{C}$. After dealkylation and work-up, adefovir could be isolated in $64 \%$ yield (Scheme 9). It should be noted 
that when $3 \mathrm{~N} \mathrm{H}_{2} \mathrm{SO}_{4} / \mathrm{NH}_{3}$ was used for dealkylation/pH adjustment, the formation of an insoluble adefovir-salt was observed.

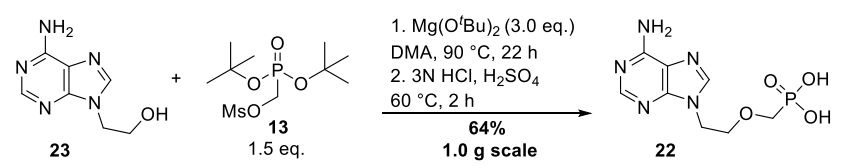

Scheme 9: Synthesis of adefovir (22) using (di-tert-butoxyphosphoryl)methyl methanesulfonate (13).

\section{Conclusion}

A new practical two-step sequence for the synthesis of tenofovir was developed using the hitherto unknown (di-tert-butoxyphosphoryl)methyl 4-methylbenzenesulfonate (13) and (di-tertbutoxyphosphoryl)methyl methanesulfonate (14). These crystalline key intermediates could be synthesized in gram amounts using straightforward chemistry and avoiding any chromatography step. The newly developed tert-butyl phosphite synthesis allowed a simple and multigram preparation of sufficiently pure starting material. The crude di-tert-butyl phosphite was hydroxymethylated through an optimized protocol whereby crystalline di-tert-butyl (hydroxymethyl)phosphonate could directly be obtained from the filtered reaction mixture.

Manufacturing costs of the tert-butyl oxymethyl phosphonates are probably higher than those of the commonly used ethyl derivative. Nevertheless, higher expenses can be compensated by much smoother and cheaper conditions for deprotection as well as by an overall simpler process. Furthermore, the use of mesylate instead of tosylate as the leaving group in the alkylation of HPA is more atom-economical. The herein developed protocol allows a quick and efficient access to compounds showing an oxymethyl phosphonate moiety which can also be beneficial for prospective research. 


\section{Experimental section}

All employed chemicals were commercially available and used without prior purification. Anhydrous THF, Me-THF, CPME, MTBE were freshly distilled over potassium (DCM over $\left.\mathrm{CaH}_{2}\right)$ under nitrogen atmosphere. Anhydrous DMF, DMA, DMSO and NMP were purchased from Acros (AcroSeal $\left.{ }^{\mathrm{TM}}\right)$. Oven-dried glass ware was dried in an oven at $150^{\circ} \mathrm{C}$ overnight, closed with a plug and a septum while still hot, cooled to room temperature and then purged with nitrogen. NMR spectra were recorded on a Bruker Avance-III HD instrument $\left({ }^{1} \mathrm{H}-\mathrm{NMR}\right.$ : $300 \mathrm{MHz},{ }^{13} \mathrm{C}-$ NMR: $\left.75 \mathrm{MHz},{ }^{31} \mathrm{P}-\mathrm{NMR}: 121 \mathrm{MHz}\right)$ or a Bruker Avance-III HD instrument $\left({ }^{1} \mathrm{H}-\mathrm{NMR}\right.$ : $400 \mathrm{MHz}$, ${ }^{13} \mathrm{C}-\mathrm{NMR}: 101 \mathrm{MHz},{ }^{31} \mathrm{P}-\mathrm{NMR}: 162 \mathrm{MHz}$ ) with a $5 \mathrm{~mm}$ BBFO probe. The chemical shifts $\delta$ were expressed in ppm downfield from tetramethylsilane $\left({ }^{1} \mathrm{H}-\mathrm{NMR},{ }^{13} \mathrm{C}-\mathrm{NMR}\right)$. Deuterated solvents $\left(\mathrm{CDCl}_{3}, \mathrm{DMSO}-\mathrm{d}_{6}\right)$ served as internal reference. The reported signal splittings were abbreviated as follows: $\mathrm{s} b=$ broad singlet, $\mathrm{s}=$ singlet, $\mathrm{d}=$ doublet, $\mathrm{t}=$ triplet. Coupling constants $J$ are reported in Hz. ESI-MS spectra were recorded on a 1260-series Infinity II HPLC-system (AgilentTechnologies) with a binary pump and integrated diode array detector coupled to a LC/MSD Infinitylab LC/MSD (G6125B LC/MSD) mass spectrometer. For high resolution (HR) mass spectra an Agilent 6545 Q-TOF spectrometer and a suitable external calibrant was used. Analytical HPLC was carried out with an Agilent 1260 Infinity system equipped with a binary pump, a diode array detector and LC/MSD Infinitylab LC/MSD (G6125B LC/MSD) mass spectrometer. A ACE C18 PFP column $\left(3 \mu \mathrm{m}, 4.6 \mathrm{~mm} \times 150 \mathrm{~mm}, 40{ }^{\circ} \mathrm{C}\right)$ with gradient elution using acetonitrile/ water $(+0.1 \%$ formic acid) as solvent and a flow rate of $1.0 \mathrm{~mL} / \mathrm{min}$ was used. Gas chromatography was performed on an Agilent 8890 gas chromatograph equipped with a 5977 GC/MS detector. An Agilent Technologies HP 5MS UI column $(30 \mathrm{~m} \times 0.25 \mathrm{~mm} \times 0.25 \mu \mathrm{m})$ as stationary phase with helium as carrier gas and a flow rate of $1.2 \mathrm{~mL} / \mathrm{min}$ was used. The following parameters were 
used: inlet temperature $250^{\circ} \mathrm{C}$, transfer line temperature $250^{\circ} \mathrm{C}$, ion source temperature $230{ }^{\circ} \mathrm{C}$, MS-quadrupole temperature $150{ }^{\circ} \mathrm{C}$ and an initial oven temperature of $40^{\circ} \mathrm{C}$ for 2 min with a temperature ramp of $50^{\circ} \mathrm{C} / \mathrm{min}$ to $320^{\circ} \mathrm{C}$ over $5.6 \mathrm{~min}$ followed by $7.4 \mathrm{~min}$ hold. IR-spectroscopy was conducted on a Bruker Tensor 27 FTIR-spectrometer using a diamond ATR unit. Thin-layer chromatography was performed on Merck $\mathrm{F}_{254}$ silica gel plates. Spots were visualized with UVlight $(\lambda=254 \mathrm{~nm})$ or stained with appropriate reagents. Melting points are uncorrected and were taken by using a Krüss KSP1N digital melting point apparatus. Water content determination was conducted with a Xylem TitroLine ${ }^{\circledR} 7500$ Karl-Fischer Titrator.

Di-tert-butyl phosphite, 8. An oven-dried Schlenk flask was charged with dry Me-THF $(300 \mathrm{~mL})$ under nitrogen atmosphere and cooled in an ice-bath. $\mathrm{PCl}_{3}(99 \%, 6.0 \mathrm{~mL}, 67.9 \mathrm{mmol}$, 1.0 eq) was added and the solution was stirred for three minutes while cooling. Under nitrogen reverse flow, $\mathrm{NaO} t \mathrm{Bu}(98 \%, 16.32 \mathrm{~g}, 166.4 \mathrm{mmol}, 2.5$ eq.) was added in small portions over five minutes while stirring properly. The ice-bath was removed and the thick colorless suspension stirred for one hour at r.t.. Saturated $\mathrm{NaHCO}_{3}$-solution $(200 \mathrm{~mL})$ was added and the mixture was stirred for five minutes. The two-phase mixture was transferred into a separating funnel and shaken vigorously. The aqueous phase was drained and the organic phase was washed again with a fresh portion of sat. $\mathrm{NaHCO}_{3}$-solution $(200 \mathrm{~mL})$. The organic phase was separated, dried over $\mathrm{NaSO}_{4}$ and all volatiles were removed in vacuo at $30^{\circ} \mathrm{C}$. Crude 9 was obtained as a colorless, slight murky liquid $(11.26 \mathrm{~g}, 57.98 \mathrm{mmol}, 85 \%)$ which was used for the next step without purification. $M$ $\left(\mathrm{C}_{8} \mathrm{H}_{19} \mathrm{O}_{3} \mathrm{P}\right)=194.21 \mathrm{~g} / \mathrm{mol}$. Boiling range: $27-31^{\circ} \mathrm{C}(0.3 \mathrm{mbar})\left(\right.$ Lit.: $\left.72-78{ }^{\circ} \mathrm{C}(13-16 \mathrm{mbar}){ }^{19}\right)$ $\mathrm{R}_{\mathrm{f}}\left(\mathrm{SiO}_{2}\right): 0.46$ (EtOAc), stained with $\mathrm{KMnO}_{4}$. IR (ATR): $v=2980,1371,1263,1173,958 \mathrm{~cm}^{-1}$. ${ }^{1} \mathrm{H}-\mathrm{NMR}, \operatorname{COSY}\left(300 \mathrm{MHz}, \mathrm{CDCl}_{3}\right): \delta=6.90\left(\mathrm{~d},{ }^{1} \mathrm{~J}_{\mathrm{P}-\mathrm{H}}=681 \mathrm{~Hz}, 1 \mathrm{H},-\mathrm{P}-\mathrm{H}\right), 1.47(\mathrm{~s}, 18 \mathrm{H},-$ $\left.\mathrm{C}\left(\mathrm{CH}_{3}\right)_{3}\right)$ ppm. ${ }^{13} \mathrm{C}-\mathrm{NMR}, \mathrm{HMBC}, \mathrm{HSQC}\left(75 \mathrm{MHz}, \mathrm{CDCl}_{3}\right): \delta=82.9\left(\mathrm{~d},{ }^{2} J_{\mathrm{C}-\mathrm{P}}=7.4 \mathrm{~Hz},-\mathrm{O}-\right.$ 
$\left.C\left(\mathrm{CH}_{3}\right)_{3}-\right), 30.5\left(\mathrm{~d},{ }^{3} J_{\mathrm{C}-\mathrm{P}}=4.6 \mathrm{~Hz},-\mathrm{CH}_{3}\right)$ ppm. ${ }^{31} \mathrm{P}-\mathrm{NMR}\left(121 \mathrm{MHz}, \mathrm{CDCl}_{3}\right): \delta=3.18 \mathrm{ppm} . \mathrm{GC}-$ MS: $m / z=83.1(100 \%)$. The spectrometric data are consistent with literature values. ${ }^{22,24}$

Di-tert-butyl (hydroxymethyl)phosphonate, 12. Variant 1: According to a method from Grimmond et al..$^{25}$ : A round-bottomed flask was charged with di-tert-butyl phosphite $\left(96 \%{ }^{2}\right.$, $3.24 \mathrm{~g}, 16.0 \mathrm{mmol}, 1.0$ eq.), $\mathrm{NEt}_{3}\left(2.6 \mathrm{~mL}, 19 \mathrm{mmol}, 1.2\right.$ eq.) and $\mathrm{H}_{2} \mathrm{O}(1 \mathrm{~mL})$. Aqueous formaldehyde solution $(37 \%, 1.20 \mathrm{~mL}, 16.0 \mathrm{mmol} 1.0 \mathrm{eq}$.) was added afterwards and the solution was stirred for $24 \mathrm{~h}$ at r.t. (reaction control by GC or ${ }^{31} \mathrm{P}-\mathrm{NMR}$ spectroscopy). $\mathrm{MeOH}(5 \mathrm{~mL}$ ) was added and all volatiles were removed in vacuo at $40{ }^{\circ} \mathrm{C}$. This procedure was repeated twice and then performed again with DCM $(3 \times 5 \mathrm{~mL})$ furnishing the crude product as slight yellowish waxy solid (3.51 g, $\left.14.5 \mathrm{mmol}, 91 \%^{3}\right)$. Variant 2: A round-bottomed flask was charged with crude ditert-butyl phosphite $\left(95 \%{ }^{4}, 11.25 \mathrm{~g}, 55.0, \mathrm{mmol}, 1.0 \mathrm{eq}.\right)$, paraformaldehyde $(97 \%, 1.70 \mathrm{~g}$, 1.0 eq.), $\mathrm{K}_{2} \mathrm{CO}_{3}{ }^{5}(1.60 \mathrm{~g}, 11.59 \mathrm{mmol}, 0.2$ eq.) and acetonitrile (hplc grade, $170 \mathrm{~mL})$. The gasfilled compartment of the flask was purged with argon for $15 \mathrm{~s}$ and immediately closed with a septum equipped with a balloon full of argon. The colorless suspension was heated at $70{ }^{\circ} \mathrm{C}$ for $20 \mathrm{~h}$ (reaction control by GC or ${ }^{31} \mathrm{P}-\mathrm{NMR}$ spectroscopy). The reaction mixture was cooled to r.t., filtered and concentrated in vacuo at $40{ }^{\circ} \mathrm{C}$ to half of the original volume. The flask was stored in a freezer overnight at $-24{ }^{\circ} \mathrm{C}$ during $\mathbf{1 2}$ crystallized out (if no crystallization took place, slightly shaking or inoculating helped). The supernatant mother liquor was decanted and the solid was washed twice with cold $\mathrm{MeCN}\left(-24{ }^{\circ} \mathrm{C}, 2 \times 5 \mathrm{~mL}\right)$. The solid was dried in vacuo at $30^{\circ} \mathrm{C}$ to afford

\footnotetext{
${ }^{2}$ Commercially available

${ }^{3}$ Yield was corrected by ${ }^{31} \mathrm{P}-\mathrm{NMR}$ spectroscopy.

${ }^{4}$ Purity was estimated by ${ }^{31} \mathrm{P}-\mathrm{NMR}$ spectroscopy

${ }^{5}$ anhydrous, grinded and stored in desiccator
} 
$12(8.90 \mathrm{~g})$. Concentrating the mother liquor and storing in a freezer overnight yielded a second pure crystallisate $(1.97 \mathrm{~g})$. In total $10.87 \mathrm{~g}\left(48.47 \mathrm{mmol}, 71 \%\right.$ related to $\left.\mathrm{PCl}_{3}\right)$ of $\mathbf{1 2}$ was obtained. $\boldsymbol{M}\left(\mathrm{C}_{9} \mathrm{H}_{21} \mathrm{O}_{4} \mathrm{P}\right)=224.24 \mathrm{~g} / \mathrm{mol}$. Melting range: $100.0-102.7^{\circ} \mathrm{C}$. $\mathbf{R}_{\mathbf{f}}\left(\mathbf{S i O}_{2}\right): 0.32$ (EtOAc), stained with $\mathrm{KMnO}_{4}$. IR (ATR): $v=3309,2980,1394,1238,1167,1038,975 \mathrm{~cm}^{-1} .{ }^{1}$ H-NMR, COSY $\left(400 \mathrm{MHz}, \mathrm{CDCl}_{3}\right): \delta=3.74\left(\mathrm{~d},{ }^{1} \mathrm{JP}_{\mathrm{P}-\mathrm{H}}=6.6 \mathrm{~Hz}, 2 \mathrm{H},-\mathrm{PCH}_{2}-\right), 2.57\left(\mathrm{~s}_{\mathrm{B}}, 1 \mathrm{H},-\mathrm{OH}\right), 1.52(\mathrm{~s}, 18 \mathrm{H},-$ $\left.\mathrm{C}\left(\mathrm{CH}_{3}\right)_{3}\right)$ ppm. ${ }^{13} \mathrm{C}-\mathbf{N M R}, \mathbf{H M B C}, \mathbf{H S Q C}\left(101 \mathrm{MHz}, \mathrm{CDCl}_{3}\right): \delta=82.9\left(\mathrm{~d},{ }^{2} J_{\mathrm{C}-\mathrm{P}}=9.0 \mathrm{~Hz},-\right.$ $\left.C\left(\mathrm{CH}_{3}\right)_{3}-\right), 60.1\left(\mathrm{~d},{ }^{1} J_{\mathrm{C}-\mathrm{P}}=164 \mathrm{~Hz},-\mathrm{P}-\mathrm{CH}_{2}-\right), 30.6\left(\mathrm{~d},{ }^{3} J_{\mathrm{C}-\mathrm{P}}=3.8 \mathrm{~Hz},-\mathrm{C}\left(\mathrm{CH}_{3}\right)_{3}\right)$ ppm. ${ }^{31} \mathbf{P}-\mathbf{N M R}$ (162 MHz, $\left.\mathrm{CDCl}_{3}\right): \delta=16.4$ ppm. GC-MS: $m / z=113.1(100 \%)$. ESI-MS: $m / z=247.1(100 \%$, $\left.[\mathrm{M}+\mathrm{Na}]^{+}\right)$. The spectrometric data are consistent with literature values. ${ }^{29}$

(Di-tert-butoxyphosphoryl)methyl 4-methylbenzenesulfonate, 13. In an oven-dried Schlenk flask di-tert-butyl (hydroxymethyl)phosphonate $(3.00 \mathrm{~g}, 13.4 \mathrm{mmol}, 1.0$ eq.), NEt 3 (2.1 mL, $14.7 \mathrm{mmol}, 1.1$ eq.) and DMAP (0.16 g, $1.34 \mathrm{mmol}, 0.1$ eq.) were dissolved in dry DCM (100 mL) under nitrogen atmosphere. Tosyl chloride ( $2.81 \mathrm{~g}, 14.7 \mathrm{mmol}, 1.1 \mathrm{eq}$.) was added and the solution stirred under nitrogen atmosphere at r.t. for $24 \mathrm{~h}$ ( $99 \%$ conversion by ${ }^{31} \mathrm{P}-\mathrm{NMR}$-spectroscopy). The reaction mixture was washed with saturated $\mathrm{NaHCO}_{3}$-solution $(70 \mathrm{~mL})$ and the organic phase was separated. After drying over $\mathrm{NaSO}_{4}$ all volatiles were removed in vacuo at $30{ }^{\circ} \mathrm{C}$ (CAUTION! High temperatures can lead to decomposition (dealkylation)). The crude product (4.93 g) was dissolved in warm EtOH $\left(17 \mathrm{~mL}\right.$, $\left.\max 50^{\circ} \mathrm{C}\right)$, cooled to r.t. and stored in a freezer $\left(-24^{\circ} \mathrm{C}\right)$ overnight. The supernatant mother liquor was decanted and the crystallized solid was washed with two portions of cold $\left(-24{ }^{\circ} \mathrm{C}\right) \mathrm{EtOH}(2 \times 3 \mathrm{~mL})$. After drying in vacuo at $30^{\circ} \mathrm{C} 13$ was obtained as a colorless solid in $87 \%$ yield $(4.41 \mathrm{~g}, 11.7 \mathrm{mmol}, 87 \%)$. For longer storage it is recommended to store the compound in a refrigerator or freezer. $\boldsymbol{M}\left(\mathrm{C}_{16} \mathrm{H}_{27} \mathrm{O}_{6} \mathrm{PS}\right)=378.42 \mathrm{~g} / \mathrm{mol}$. Melting range: 74.4-76.5 ${ }^{\circ} \mathrm{C}$ (decomposition). $\mathbf{R}_{\mathbf{f}}\left(\mathbf{S i O}_{2}\right): 0.21$ (EtOAc:Cyclohexane = 1:2). IR (ATR): $v=2979$, 
1365, 1251, 1180, 1170, 1022, $972 \mathrm{~cm}^{-1} .{ }^{1} \mathbf{H}-\mathbf{N M R}, \operatorname{COSY}\left(300 \mathrm{MHz}, \mathrm{CDCl}_{3}\right): \delta=7.82-7.77(\mathrm{~m}$, 2H, H-2), 7.37-7.33 (m, 2H, H-3), 4.01 (d, $\left.{ }^{2} J_{\mathrm{H}-\mathrm{P}}=9.9 \mathrm{~Hz}, 2 \mathrm{H},-\mathrm{P}-\mathrm{CH}_{2}\right), 2.45$ (s, 3H, Ar-CH 3$), 1.46$ (s, 18H, - $\left.\left(\mathrm{CH}_{3}\right)_{3}\right)$ ppm. ${ }^{13} \mathrm{C}-\mathrm{NMR}$, HMBC, HSQC (101 MHz, $\left.\mathrm{CDCl}_{3}\right): \delta=145.3$ (C-1), 132.2 (C-4), $130.0(\mathrm{C}-3), 128.3\left(\mathrm{C}-2,84.3\left(\mathrm{~d},{ }^{2} J_{\mathrm{C}-\mathrm{P}}=8.6 \mathrm{~Hz},-C\left(\mathrm{CH}_{3}\right)_{3}\right), 64.1\left(\mathrm{~d},{ }^{1} J_{\mathrm{C}-\mathrm{P}}=174 \mathrm{~Hz},-\mathrm{P}-\right.\right.$ $\left.\mathrm{CH}_{2}-\right), 30.4\left(\mathrm{~d},{ }^{3} \mathrm{~J}_{\mathrm{C}-\mathrm{P}}=4.0 \mathrm{~Hz},-\mathrm{C}\left(\mathrm{CH}_{3}\right)_{3}\right), 21.8\left(\mathrm{~s}, \mathrm{Ar}_{-} \mathrm{CH}_{3}\right)$ ppm. ${ }^{31} \mathbf{P}-\mathrm{NMR}\left(121 \mathrm{MHz}, \mathrm{CDCl}_{3}\right): \delta$ $=6.7 \mathrm{ppm}$. ESI-HRMS: Calcd for $[\mathrm{M}+\mathrm{Na}]^{+}: \mathrm{m} / \mathrm{z}=401.1158$, found $: \mathrm{m} / z=401.1154$.

(Di-tert-butoxyphosphoryl)methyl methanesulfonate, 14. In an oven-dried Schlenk flask ditert-butyl (hydroxymethyl)phosphonate (12.94 g, $57.71 \mathrm{mmol}, 1.0 \mathrm{eq}$.) was dissolved in dry DCM $(200 \mathrm{~mL})$ under nitrogen atmosphere. $\mathrm{NEt}_{3}(9.70 \mathrm{~mL}, 69.2 \mathrm{mmol}, 1.2 \mathrm{eq}$.) was added and the solution was cooled in an ice-bath. Mesyl chloride (4.90 mL, $63.5 \mathrm{mmol}, 1.1$ eq.) was dripped into the solution within four minutes, the ice bath was removed and the solution stirred at r.t. for $19 \mathrm{~h}$ (reaction control by TLC). The reaction mixture was washed twice with sat. $\mathrm{NaHCO}_{3}$-solution (2 x $150 \mathrm{~mL}$ ) and the organic phase was separated. After drying over $\mathrm{Na}_{2} \mathrm{SO}_{4}$ all volatiles were removed in vacuo at $30^{\circ} \mathrm{C}$ (CAUTION! High temperatures can lead to decomposition (dealkylation)). The title compound $\mathbf{1 4}$ was obtained as a orange-brown oil $(16.92 \mathrm{~g}, 55.97 \mathrm{mmol}$, 97\%) which solidified after a while. For longer storage it is recommended to store the compound in a refrigerator or freezer. $\boldsymbol{M}\left(\mathrm{C}_{10} \mathrm{H}_{23} \mathrm{O}_{6} \mathrm{PS}\right)=302.32 \mathrm{~g} / \mathrm{mol}$. Melting range: $52.2-55.0^{\circ} \mathrm{C}$ (decomposition). $\mathbf{R} \mathbf{f}\left(\mathbf{S i O}_{2}\right): 0.55$ (EtOAc), stained with $\mathrm{KMnO}_{4}$. IR (ATR): $v=2983,1359,1260$, 1174, $965 \mathrm{~cm}^{-1} .{ }^{1} \mathrm{H}-\mathrm{NMR}, \mathbf{C O S Y}\left(400 \mathrm{MHz}, \mathrm{CDCl}_{3}\right): \delta=4.28\left(\mathrm{~d},{ }^{1} J_{\mathrm{P}-\mathrm{H}}=8.7 \mathrm{~Hz}, 2 \mathrm{H},-\mathrm{P}_{-} \mathrm{CH}_{2}-\right)$, $3.12\left(\mathrm{~s}, 3 \mathrm{H},-\mathrm{CH}_{3}\right), 1.53$ (s, $\left.18 \mathrm{H},-\mathrm{C}\left(\mathrm{CH}_{3}\right)_{3}\right)$ ppm. ${ }^{13} \mathbf{C}-\mathbf{N M R}, \mathbf{H M B C}, \mathbf{H S Q C}\left(75 \mathrm{MHz}, \mathrm{CDCl}_{3}\right)$ : $\delta=84.5\left(\mathrm{~d},{ }^{2} J_{\mathrm{C}-\mathrm{P}}=8.5 \mathrm{~Hz},-C\left(\mathrm{CH}_{3}\right)_{3}-\right), 64.2\left(\mathrm{~d},{ }^{1} J_{\mathrm{C}-\mathrm{P}}=174 \mathrm{~Hz},-\mathrm{P}-\mathrm{CH}_{2}-\right), 38.2\left(-\mathrm{CH}_{3}\right), 30.5\left(\mathrm{~d},{ }^{3} J_{\mathrm{C}-}\right.$ $\left.\mathrm{P}=3.9 \mathrm{~Hz},-\mathrm{C}\left(\mathrm{CH}_{3}\right)_{3}\right)$ ppm. ${ }^{31} \mathbf{P}-\mathbf{N M R}\left(162 \mathrm{MHz}, \mathrm{CDCl}_{3}\right): \delta=7.2 \mathrm{ppm}$. ESI-HRMS: Calcd for $[\mathrm{M}+\mathrm{H}]^{+}: m / z=303.1026$, found: $m / z=303.1026$. 
Tenofovir (PMPA), 1. Variant 1 using mesylate 14: An oven-dried Schlenk flask was charged with HPA (4, >98\%, $5.00 \mathrm{~g}, 25.9 \mathrm{mmol} 1.0$ eq.) and magnesium tert-butoxide (93\%, 14.24. g, $77.64 \mathrm{mmol}, 3.0$ eq.) under nitrogen atmosphere. Dry DMA (65 mL) was added and the suspension was stirred at $90{ }^{\circ} \mathrm{C}$ for $30 \mathrm{~min}$. While purging with nitrogen (di-tertbutoxyphosphoryl)methyl methanesulfonate $(\mathbf{1 4}, 11.74 \mathrm{~g}, 38.82 \mathrm{mmol}, 1.5 \mathrm{eq}$.$) was added portion$ wise within one minute. The reaction mixture was stirred at $90{ }^{\circ} \mathrm{C}$ for $22 \mathrm{~h}(90 \%$ conversion of HPA detected by HPLC at $254 \mathrm{~nm}$ ). All volatiles were removed in vacuo at $50-60{ }^{\circ} \mathrm{C}$ and $1.5 \mathrm{M}$ $\mathrm{H}_{2} \mathrm{SO}_{4}(50 \mathrm{~mL})$ was added to the orange-brownish residue. During heating to $60{ }^{\circ} \mathrm{C}$ a yellowish solution formed. After four hours (complete dealkylation to PMPA detected by HPLC at $254 \mathrm{~nm}$ ) the solution was cooled in an ice bath. Additional water $(20 \mathrm{~mL})$ was added and the $\mathrm{pH}$ was adjusted to $\mathrm{pH}=2.8-3$ using conc. $\mathrm{NH}_{3}$-solution $(25 \mathrm{wt} \%, 3 \mathrm{~mL})$. A colorless to slight yellowish suspension formed which was stirred while cooling for one hour and then stored in a refrigerator overnight. The next day, the suspension was vacuum-filtered and washed with ice-cold water ( $4 \mathrm{x}$ $4 \mathrm{~mL})$ and ice-cold acetone $(3 \times 4 \mathrm{~mL})$. The filtered solid was first dried on the air and then at $80{ }^{\circ} \mathrm{C}$ under high vacuum for four hours to obtain PMPA as a colorless powder $(5.36 \mathrm{~g}, 18.6 \mathrm{mmol}$, 72\%). Variant 2 using tosylate 13: An oven-dried Schlenk flask was charged with HPA (4,>98\%, $1.00 \mathrm{~g}, 5.18 \mathrm{mmol}, 1.0$ eq.) and magnesium tert-butoxide (93\%, $2.85 \mathrm{~g}, 15.5 \mathrm{mmol}, 3.0$ eq.) under nitrogen atmosphere. Dry DMF $(12 \mathrm{~mL})$ was added and the suspension was stirred at $80{ }^{\circ} \mathrm{C}$ for 25-30 min. While purging with nitrogen (di-tert-butoxyphosphoryl)methyl 4methylbenzenesulfonate $(\mathbf{1 3}, 2.94 \mathrm{~g}, 7.76 \mathrm{mmol}, 1.5 \mathrm{eq}$.$) was added portion wise within one$ minute. The reaction mixture was stirred at $80{ }^{\circ} \mathrm{C}$ for $23 \mathrm{~h}(95 \%$ conversion of HPA detected by HPLC at $\lambda=254 \mathrm{~nm})$. All volatiles were removed in vacuo and $1.5 \mathrm{M} \mathrm{H}_{2} \mathrm{SO}_{4}(10 \mathrm{~mL})$ was added to the orange-brownish residue. During heating to $60{ }^{\circ} \mathrm{C}$ a yellowish solution formed. After four 
hours (complete dealkylation to PMPA detected by HPLC at $\lambda=254 \mathrm{~nm}$ ) the solution was cooled in an ice bath and the $\mathrm{pH}$ was adjusted to $\mathrm{pH}=2.8-3$ using conc. $\mathrm{NH}_{3}$-solution $(25 \%, 0.6 \mathrm{~mL}$, additional water (2-3 mL) was added for better stirring). A colorless to slight yellowish suspension formed which was stirred for one further hour while cooling and then stored in a refrigerator overnight. The suspension was vacuum-filtered and the filter cake was washed with ice-cold water $(3 \times 2 \mathrm{~mL})$ and ice-cold acetone $(3 \times 2 \mathrm{~mL})$. The filtered solid was first dried on the air and then then at $80^{\circ} \mathrm{C}$ under high-vacuum for four hours. PMPA was obtained as a colorless powder $(1.01 \mathrm{~g}, 3.52 \mathrm{mmol}, 68 \%) . M\left(\mathrm{C}_{9} \mathrm{H}_{14} \mathrm{~N}_{5} \mathrm{O}_{4} \mathrm{P}\right)=287.22 \mathrm{~g} / \mathrm{mol}$. Melting range: $271-274{ }^{\circ} \mathrm{C}$ (decomposition), (Lit.: $276-278{ }^{\circ} \mathrm{C}^{30}$ ). Water content: $2.3 \%$ (determined by Karl-Fischer Titrator). $\mathbf{R}_{\mathbf{f}}\left(\mathbf{C}_{18}-\mathbf{S i O}_{2}\right): 0.38\left(\mathrm{H}_{2} \mathrm{O}\right)$. IR (ATR): $v=3383,3216,3108,2933,1696,1666,1616$, 1410, 1237, 1074, $933 \mathrm{~cm}^{-1} .{ }^{1}$ H-NMR, COSY (300 MHz, DMSO-d 6 ): $\delta=8.17$ (s, $\left.1 \mathrm{H}, \mathrm{H}-8\right), 8.15$ (s, 1H, H-2), $7.43\left(\mathrm{~s}_{\mathrm{B}}, 2 \mathrm{H},-\mathrm{NH}_{2}\right), 4.29\left(\mathrm{dd},{ }^{2} J=14.3 \mathrm{~Hz},{ }^{3} J=4.0 \mathrm{~Hz}, 1 \mathrm{H},-\mathrm{NC} H_{a} \mathrm{H}-\right), 4.16\left(\mathrm{dd},{ }^{2} J\right.$ $\left.=14.3 \mathrm{~Hz},{ }^{3} \mathrm{~J}=5.6 \mathrm{~Hz}, 1 \mathrm{H},-\mathrm{NCH} H_{b} \mathrm{H}-\right), 3.95-3.85\left(\mathrm{~m}, 1 \mathrm{H},-\mathrm{CH}\left(\mathrm{CH}_{3}\right) \mathrm{O}-\right)$, 3.66-3.51 (m, 2H, $\left.\mathrm{OCH}_{2} \mathrm{P}-\right), 1.02\left(\mathrm{~d},{ }^{3} \mathrm{~J}=6.2 \mathrm{~Hz}, 3 \mathrm{H},-\mathrm{CH}_{3}\right) \mathrm{ppm} .{ }^{13} \mathrm{C}-\mathrm{NMR}, \mathbf{H M B C}, \mathbf{H S Q C}(75 \mathrm{MHz}$, DMSO$\left.\mathrm{d}_{6}\right): \delta=155.5(\mathrm{C}-6), 151.7(\mathrm{C}-2), 149.7(\mathrm{C}-4), 141.9(\mathrm{C}-8), 118.2(\mathrm{C}-5), 75.3\left(\mathrm{~d},{ }^{3} J_{\mathrm{C}-\mathrm{P}}=12.1 \mathrm{~Hz}\right.$ $\left.-\mathrm{CH}\left(\mathrm{CH}_{3}\right) \mathrm{O}-\right), 64.5\left(\mathrm{~d},{ }^{1} J_{\mathrm{C}-\mathrm{P}}=162 \mathrm{~Hz},-\mathrm{OCH}_{2} \mathrm{P}-\right), 46.5\left(-\mathrm{NCH}_{2}-\right), 17.0\left(-\mathrm{CH}_{3}\right) \mathrm{ppm} .{ }^{31} \mathbf{P}-\mathbf{N M R}$ (121 MHz, DMSO-d 6$): \delta=16.2$ ppm. ESI-MS: $m / z=288.1\left(100 \%,[\mathrm{M}+\mathrm{H}]^{+}\right)$. The spectrometric data are consistent with literature values. ${ }^{10}$

\{[(4-Methylbenzenesulfonyl)oxy]methyl\}phosphonic acid, 7. In an oven-dried Schlenk flask di-tert-butoxyphosphoryl)methyl 4-methylbenzenesulfonate $(\mathbf{1 3}, 0.099 \mathrm{~g}, 0.26 \mathrm{mmol})$ was heated to $100^{\circ} \mathrm{C}$ while purging with nitrogen. After the solid has melted it was stirred for further $15 \mathrm{~min}$ and then cooled to r.t.. 7 was obtained as a colorless resin $(0.070 \mathrm{~g}, 0.26 \mathrm{mmol}$, quant.) which formed a colorless solid by trituration. $\boldsymbol{M}\left(\mathrm{C}_{8} \mathrm{H}_{11} \mathrm{O}_{6} \mathrm{PS}\right)=266.20 \mathrm{~g} / \mathrm{mol}$. Melting range: $133.8-$ 
$134.8^{\circ} \mathrm{C} . \mathbf{R}_{\mathbf{f}}\left(\mathbf{S i O}_{2}\right): 0.19$ (EtOAc $+10 \%$ HOAc), stained with Seebach-reagent. $\quad$ IR (ATR): $v$ $=1365,1239,1178,1026,939 \mathrm{~cm}^{-1} .{ }^{1} \mathbf{H}-\mathbf{N M R}, \mathbf{C O S Y}\left(400 \mathrm{MHz}, \mathrm{DMSO}-\mathrm{d}_{6}\right): \delta=7.84-7.75(\mathrm{~m}$, 2H, H-2), 7.53-7.45 (m, 2H, H-3), $3.95\left(\mathrm{~d},{ }^{2} \mathrm{~J}_{\mathrm{P}-\mathrm{H}}=10.0 \mathrm{~Hz}, 2 \mathrm{H},-\mathrm{CH}_{2}-\right), 2.43\left(\mathrm{~s}, 3 \mathrm{H},-\mathrm{CH}_{3}\right) \mathrm{ppm}$. ${ }^{13}$ C-NMR, HMBC, HSQC (75 MHz, DMSO-d 6 ): $\delta=145.4$ (C-1), 131.3 (C-4), 130.3 (C-3), 128.0 $(\mathrm{C}-2), 64.0\left(\mathrm{~d},{ }^{2} J_{\mathrm{C}-\mathrm{P}}=159 \mathrm{~Hz},-\mathrm{CH}_{2}-\right), 21.2\left(-\mathrm{CH}_{3}\right)$ ppm. ${ }^{31} \mathbf{P}-\mathbf{N M R}\left(162 \mathrm{MHz}, \mathrm{DMSO}-\mathrm{d}_{6}\right): \delta=$ 9.5 ppm. ESI-MS: $m / z=266.9\left(100 \%,[\mathrm{M}+\mathrm{H}]^{+}\right)$. The spectrometric data are consistent with literature values. ${ }^{10}$

$\{[($ Methylsulfonyl)oxy]methyl $\}$ phosphonic acid, 21. In an oven-dried Schlenk flask (di-tertbutoxyphosphoryl)methyl methanesulfonate $(\mathbf{1 4}, 0.10 \mathrm{~g}, 0.33 \mathrm{mmol})$ was heated to $85^{\circ} \mathrm{C}$ while purging with nitrogen. After the solid has melted it was stirred for further $15 \mathrm{~min}$ and then cooled to r.t.. 21 was obtained as reddish oil $(0.063 \mathrm{~g}, 0.33 \mathrm{mmol}$, quant.) which formed a colorless to slight reddish solid by trituration. $\boldsymbol{M}\left(\mathrm{C}_{2} \mathrm{H}_{7} \mathrm{O}_{6} \mathrm{PS}\right)=190.11 \mathrm{~g} / \mathrm{mol}$. Melting range: $94.2-96.5{ }^{\circ} \mathrm{C}$. $\mathbf{R}_{\mathbf{f}}\left(\mathbf{C}_{18}-\mathrm{SiO}_{2}\right): 0.46\left(\mathrm{H}_{2} \mathrm{O}+3 \% \mathrm{HOAc}\right) . \mathbf{I R}(\mathbf{A T R}): v=1365,1178,1026,1011,939 \mathrm{~cm}^{-1} .{ }^{1} \mathbf{H}-$ NMR, COSY (400 MHz, DMSO-d $\left.{ }_{6}\right): \delta=4.23\left(\mathrm{~d},{ }^{2} J_{\mathrm{P}-\mathrm{H}}=9.6 \mathrm{~Hz}, 2 \mathrm{H},-\mathrm{P}_{-} \mathrm{CH}_{2}-\right), 3.22\left(\mathrm{~s}, 3 \mathrm{H},-\mathrm{CH}_{3}\right)$ ppm. ${ }^{13}$ C-NMR, HMBC, HSQC (101 MHz, DMSO-d 6$): \delta=64.2\left(\mathrm{~d},{ }^{1} J_{\mathrm{C}-\mathrm{P}}=160 \mathrm{~Hz},-\mathrm{P}-\mathrm{CH}_{2}-\right)$, $36.5\left(\mathrm{~s},-\mathrm{CH}_{3}\right)$ ppm. ${ }^{31}$ P-NMR (162 MHz, DMSO-d 6 ): $\delta=10.4$ ppm. ESI-HRMS: Calcd for $[\mathrm{M}+\mathrm{H}]^{+}: m / z=190.9774$, found: $m / z=190.9776$.

Adefovir (PMEA), 22. An oven-dried Schlenk flask was charged with HEA (23, >98\%, $1.00 \mathrm{~g}$, $5.58 \mathrm{mmol}, 1.0$ eq.) and magnesium tert-butoxide $(93 \%, 3.07 \mathrm{~g}, 16.7 \mathrm{mmol}, 3.0 \mathrm{eq}$.$) under$ nitrogen atmosphere. Dry DMA $(12 \mathrm{~mL})$ was added and the suspension was stirred at $90{ }^{\circ} \mathrm{C}$ for 30 min. While purging with nitrogen (di-tert-butoxyphosphoryl)methyl methanesulfonate (XX, $2.53 \mathrm{~g}, 8.37 \mathrm{mmol}, 1.5$ eq.) was added portion wise within one minute. The reaction mixture stirred at $90{ }^{\circ} \mathrm{C}$ for $22 \mathrm{~h}$ (conversion of HEA $87 \%$ detected by HPLC at $254 \mathrm{~nm}$ ). All volatiles were 
removed in vacuo at $50-60{ }^{\circ} \mathrm{C}$ and $3 \mathrm{~N} \mathrm{HCl}(10 \mathrm{~mL})$ was added to the orange-brownish residue. During heating to $60{ }^{\circ} \mathrm{C}$ an orange solution formed. After four hours (complete dealkylation to PMEA detected by HPLC at $254 \mathrm{~nm}$ ) the solution was cooled in an ice bath and the $\mathrm{pH}$ was adjusted to $\mathrm{pH}=2.8-3$ using $\mathrm{NaOH}$-solution ( $40 \mathrm{wt} \%, 4-5$ drops). A colorless to slight yellowish thick suspension formed (additional water $(3 \mathrm{~mL})$ was added for better stirring) which was stirred while cooling for one hour and then stored in a refrigerator overnight. The suspension was vacuumfiltered and washed with ice-cold water $(4 \times 2 \mathrm{~mL})$ and ice-cold acetone $(3 \times 2 \mathrm{~mL})$. The filtered solid was first dried on the air and then at $80^{\circ} \mathrm{C}$ under high vacuum for three hours to obtain PMEA $(0.98 \mathrm{~g}, 3.59 \mathrm{mmol}, 64 \%) \cdot \boldsymbol{M}\left(\mathrm{C}_{8} \mathrm{H}_{12} \mathrm{~N}_{5} \mathrm{O}_{4} \mathrm{P}\right)=273.19 \mathrm{~g} / \mathrm{mol}$. Melting range: $276-278^{\circ} \mathrm{C}$ (decomposition), (Lit.: $282-284{ }^{\circ} \mathrm{C}^{31}$ ). Water content: $1.1 \%$ (determined by Karl-Fischer Titrator). Rf(C $\left.\mathbf{C} 18-S_{1} \mathbf{O}_{2}\right): 0.60\left(\mathrm{H}_{2} \mathrm{O}\right)$. IR (ATR): $v=3059,2983,1698,1519,1411,1153,1122$, 1056, $1041 \mathrm{~cm}^{-1}{ }^{1}{ }^{1} \mathrm{H}-\mathbf{N M R}, \mathbf{C O S Y}\left(400 \mathrm{MHz}, \mathrm{D}_{2} \mathrm{O}\right): \delta=8.41(\mathrm{~s}, 1 \mathrm{H}, \mathrm{H}-8), 8.38(\mathrm{~s}, 1 \mathrm{H}, \mathrm{H}-2), 4.51$ $\left(\mathrm{t},{ }^{3} \mathrm{~J}=5.0 \mathrm{~Hz}, 2 \mathrm{H},-\mathrm{NCH}_{2}-\right), 3.98\left(\mathrm{t},{ }^{3} \mathrm{~J}=5.0 \mathrm{~Hz}, 2 \mathrm{H},-\mathrm{OCH}_{2}-\right), 3.63\left(\mathrm{~d},{ }^{2} J=8.7 \mathrm{~Hz}, 2 \mathrm{H},-\mathrm{OCH}_{2} \mathrm{P}-\right.$ ) ppm. ${ }^{13}$ C-NMR, HMBC, HSQC (101 MHz, $\left.\mathrm{D}_{2} \mathrm{O}\right): \delta=150.2$ (C-6), 148.6 (C-4), 145.2 (C-8), 144.8 (C-2), 117.9 (C-5), 70.3 (d, $\left.{ }^{3} J_{\mathrm{C}-\mathrm{P}}=11.6 \mathrm{~Hz},-\mathrm{CH}_{2} \mathrm{O}-\right), 66.9$ (d, $\left.{ }^{1} J_{\mathrm{C}-\mathrm{P}}=157 \mathrm{~Hz},-\mathrm{OCH}_{2} \mathrm{P}-\right)$, $44.0\left(-\mathrm{NCH}_{2}-\right)$ ppm. ${ }^{31} \mathbf{P}-\mathrm{NMR}\left(121 \mathrm{MHz}, \mathrm{D}_{2} \mathrm{O}\right): \delta=15.6 \mathrm{ppm}$. ESI-MS: $\mathrm{m} / \mathrm{z}=274.0(100 \%$, $\left.[\mathrm{M}+\mathrm{H}]^{+}\right)$. The spectrometric data are consistent with literature values. ${ }^{31}$

\section{Associated content}

Supporting Information

Chromatograms and NMR-spectra (PDF).

\section{AUTHOR INFORMATION}

Corresponding Author 
Till Opatz - Department of Chemistry, Johannes Gutenberg-University, Duesbergweg 10-14, 55128 Mainz, Germany, Email: opatz@uni-mainz.de

Funding

This work was supported by the Bill and Melinda Gates Foundation.

Notes

The authors declare no competing financial interest.

\section{ACKNOWLEDGMENT}

We thank all members of the Medicines for All Institute for their biweekly insights, Dr J. C. Liermann (Mainz) for NMR spectroscopy and Dr C. J. Kampf (Mainz) for mass spectrometry.

References

(1) Balzarini, J.; Holy, A.; Jindrich, J.; Naesens, L.; Snoeck, R.; Schols, D.; Clercq, E. de. Differential antiherpesvirus and antiretrovirus effects of the (S) and (R) enantiomers of acyclic nucleoside phosphonates: Potent and selective in vitro and in vivo antiretrovirus activities of (R)9-(2-phosphonomethoxypropyl)-2,6-diaminopurine. Antimicrobial Agents and Chemotherapy 1993, 37, 332-338.

(2) Clercq, E. de. Anti-HIV drugs: 25 compounds approved within 25 years after the discovery of HIV. International Journal of Antimicrobial Agents 2009, 33, 307-320.

(3) Clercq, E. de. Tenofovir alafenamide (TAF) as the successor of tenofovir disoproxil fumarate (TDF). Biochemical Pharmacology 2016, 119, 1-7. 
(4) Jockusch, S.; Tao, C.; Li, X.; Anderson, T. K.; Chien, M.; Kumar, S.; Russo, J. J.;

Kirchdoerfer, R. N.; Ju, J. A library of nucleotide analogues terminate RNA synthesis catalyzed by polymerases of coronaviruses that cause SARS and COVID-19. Antiviral Research 2020, 180, 104857.

(5) del Amo, J.; Polo, R.; Moreno, S.; Díaz, A.; Martínez, E.; Arribas, J. R.; Jarrín, I.; Hernán, M. A. Incidence and Severity of COVID-19 in HIV-Positive Persons Receiving Antiretroviral Therapy. Annals of Internal Medicine 2020, DOI: 10.7326/M20-3689.

(6) https://clinicaltrials.gov/ct2/show/NCT04334928 (accessed August 30, 2020).

(7) Arimilli et al., U.S. Patent 5,922,695, Jul. 13, 1999.

(8) Brown Ripin, D. H.; Teager, D. S.; Fortunak, J.; Basha, S. M.; Bivins, N.; Boddy, C. N.; Byrn, S.; Catlin, K. K.; Houghton, S. R.; Jagadeesh, S. T. et al. Process Improvements for the Manufacture of Tenofovir Disoproxil Fumarate at Commercial Scale. Org. Process Res. Dev. 2010, 14, 1194-1201.

(9) Riley, D. L.; Walwyn, D. R.; Edlin, C. D. An Improved Process for the Preparation of Tenofovir Disoproxil Fumarate. Org. Process Res. Dev. 2016, 20, 742-750.

(10) Derstine, B. P.; Tomlin, J. W.; Peck, C. L.; Dietz, J.-P.; Herrera, B. T.; Cardoso, F. S. P.; Paymode, D. J.; Yue, A. C.; Arduengo, A. J.; Opatz, T. et al. An Efficient Synthesis of Tenofovir (PMPA): A Key Intermediate Leading to Tenofovir-Based HIV Medicines. Org. Process Res. Dev. 2020, 24, 1420-1427.

(11) Arimilli et al., U.S. Patent RE38,333 E, Nov. 25, 2003. 
(12) Jansa, P.; Baszczyňski, O.; Procházková, E.; Dračínský, M.; Janeba, Z. Microwave-assisted hydrolysis of phosphonate diesters: An efficient protocol for the preparation of phosphonic acids. Green Chem. 2012, 14, 2282.

(13) Indukuri et al.,U.S. Patent US2014/0303368 A1, Oct. 9, 2014.

(14) Elbert, T.; Břehová, P.; Holý, A. The preparation of 3H-labeled acyclic nucleoside phosphonates and study of their stability. Collect. Czech. Chem. Commun. 2010, 75, 757-766.

(15) Janeba et al., WO 2015/051874 A1, April 16, 2015.

(16) Engelsma, S. B.; Meeuwenoord, N. J.; Overkleeft, H. S.; van der Marel, G. A.; Filippov, D. V. Combined Phosphoramidite-Phosphodiester Reagents for the Synthesis of Methylene Bisphosphonates. Angew. Chem. Int. Ed. 2017, 56, 2955-2959.

(17) Clinch, K.; Crump, D. R.; Evans, G. B.; Hazleton, K. Z.; Mason, J. M.; Schramm, V. L.; Tyler, P. C. Acyclic phosph(on)ate inhibitors of Plasmodium falciparum hypoxanthine-guaninexanthine phosphoribosyltransferase. Bioorganic \& Medicinal Chemistry 2013, 21, 5629-5646.

(18) Kosolapoff, G. M. Preparation of a t-Alkyl Phosphite. J. Am. Chem. Soc. 1952, 74, 4953.

(19) Young, R. W. Di-t-butyl Phosphonate. J. Am. Chem. Soc. 1953, 75, 4620.

(20) Gerrard, W.; Isaacs, M. J. D.; Machell, G.; Smith, K. B.; Wyvill, P. L. 394. Interaction of phosphorus trichloride with alcohols and with hydroxy-esters. J. Chem. Soc. 1953, 1920.

(21) Cherbuliez, E.; Gandillon, C.; Picciotto, A. de; Rabinowitz, J. Recherches sur la formation et la transformation des esters XVIII. Sur la phosphorylation d'alcools tertiaires et sur la vitesse d'hydrolyse des esters mono-t-alcoylphosphoriques. Helv. Chim. Acta 1959, 42, 2277-2284. 
(22) Goldwhite, H.; Saunders, B. C. 462. Esters containing phosphorus. Part XIV. Some tert.Butyl esters and their reactions. J. Chem. Soc. 1957, 2409.

(23) Lapidot, A.; Samuel, D.; Weiss-Broday, M. 127. The synthesis and hydrolysis of t-butyl phosphate. J. Chem. Soc. 1964, 637.

(24) Mark, V.; van Wazer, J. R. Tri-t-butyl Phosphite and Some of Its Reactions. J. Org. Chem. 1964, 29, 1006-1008.

(25) Grimmond et al., U.S. Patent US2014/0086846 A1, Mar. 27, 2014.

(26) Du et al., WO 2019/090111 A1, May 9, 2019.

(27) J. J.Kopcho et al., US2003/0225277 A1, Dec. 4, 2003.

(28) M.W. Becker et al., US2004/0018150 A1, Jan. 29, 2004.

(29) Sowa, S.; Pietrusiewicz, K. M. Chemoselective Reduction of the $\mathrm{P}=\mathrm{O}$ Bond in the Presence of P-O and P-N Bonds in Phosphonate and Phosphinate Derivatives. Eur. J. Org. Chem. 2019, 2019, 923-938.

(30) Holý, A.; Dvořáková, H.; Masojídková, M. Synthesis of Enantiomeric N-(2Phosphonomethoxypropyl) Derivatives of Purine and Pyrimidine Bases. II. The Synthon Approach. Collect. Czech. Chem. Commun. 1995, 60, 1390-1409.

(31) Schwalbe, C. H.; Thomson, W.; Freeman, S. Structural studies on bio-active molecules. Part 17. Crystal structure of 9-(2'-phosphonomethoxyethyl)adenine (PMEA). J. Chem. Soc., Perkin Trans. 1 1991, 5, 1348-1349. 